\title{
Complementarity Between In-house R\&D and Technology Purchasing: Evidence from Chinese Manufacturing Firms
}

\author{
Jun Hou, ${ }^{1}$ Pierre Mohnen ${ }^{1,2}$ \\ ${ }^{1}$ UNU-MERIT, Maastricht 6211 TC, The Netherlands \\ ${ }^{2}$ Maastricht University, P.O. Box 616, Maastricht 6200 MD, The Netherlands
}

October 13, 2012

\begin{abstract}
In order to catch up with the current technological frontier, firms, especially in developing countries, try to acquire technological advancement through internal R\&D efforts, as well as through external technology-sourcing activities. This study tests whether these two sources of technology acquisition are complements or substitutes for each other in small and medium-size Chinese manufacturing firms. The evidence that we present shows some signs of complementarity between the two sources of knowledge in reaching a higher unconditional intensity of product innovation for firms with 100 to 300 employees, and, in genera, a significant degree of substitutability between them in achieving higher levels of labour productivity.
\end{abstract}

Keywords: R\&D, technology purchasing, complementarity, China, manufacturing

JEL codes: O33

Acknowledgement: This paper was produced as part of the SCIFI-GLOW Collaborative Project supported by the European Commission's Seventh Framework Programme for Research and Technological Development, under the Socio-economic Sciences and Humanities theme (contract no. SSH7-CT-2008217436). We thank two anonymous referees for their very useful comments. 


\section{Introduction}

In order to catch up with the current technological frontier, firms in developing countries have been striving to promote technological advance through internal research and development efforts (in-house R\&D), as well as through external technology purchasing (TP). In-house R\&D expenditure includes the capital, labour, and design costs associated with research and development. TP involves purchasing, transferring, or licensing new technologies from the domestic or the international market. For firms in developing countries, establishing efficient innovation strategies could accelerate their technological advance and contribute to their economic development.

In China, the central government has established a series of policy incentives to encourage firms to carry out in-house R\&D activities, ${ }^{1}$ and these policies have greatly increased China's capability to develop its own technology, and to assimilate and improve the technology transferred from advanced economies ( $\mathrm{Lu}$ and Lazonick, 2001). With great emphasis placed on 'indigenous innovation',2 do Chinese firms still need external technology sourcing? Is there a synergetic benefit from engaging in both internal R\&D and technology purchasing? The goal of this research is to answer these questions by testing whether there is a relationship of complementarity between the two sources of knowledge acquisition. In other words, do $\mathrm{R} \& \mathrm{D}$ and technology purchases reinforce each other in achieving higher innovation output and/or higher levels of productivity?

The data on which the empirical analysis is based come from the World Bank Investment Climate Survey (ICS $)^{3}$ relating to China in the year 2003. This dataset provides continuous data on R\&D and technology purchases. The results exhibit some evidence of complementarity between in-house R\&D and TP in raising the sales of new products per employee in small-sized Chinese manufacturing firms with 100 to 300 employees. In-house $\mathrm{R} \& \mathrm{D}$ seems to accelerate the assimilation of external expertise, while external technology sourcing enhances the efficiency of in-house innovation activities. However, we find that R\&D and TP are substitutes when it comes to raising labour productivity. Only for firms with fewer than 100 employees is there a complementarity visible in terms of labour productivity.

The next section sets the background by reviewing the existing evidence on complementarity between internal and external technology acquisition in developing countries, and by describing the evolution of the policy of technology acquisition in China. Section 3 defines the notion of complementarity and the

\footnotetext{
${ }^{1}$ Especially after 1995, policies were designed to accelerate indigenous science and technology development. The number of patent applications from domestic applicants was 10,011 in 1995, and it has increased dramatically ever since. The number reached 39,806 by 2002 and 255,832 by 2011 (China Patent Office, 2012). http://www.english.sipo.gov.cn/.

2 Indigenous innovation means 'to develop the capability to conduct R\&D or create innovation internally'.

${ }^{3}$ For more information on the Investment Climate Survey, see http://www.worldbank.org.
} 
specification of the model used in the empirical analysis. The data and the variables used will be presented in section 4. The results are interpreted in section 5. Section 6 summarizes and concludes.

\section{Background}

\subsection{In-house R\&D and technology purchasing: complements or substitutes?}

A large number of empirical studies have estimated the relationship between innovation-sourcing strategies in developing countries. Results are mixed. One group of studies concludes that internal R\&D and external technology are substitutes for each other. Firms decide to develop technology by themselves and/or buy it from outside, given a limited budget. An increase in either of the two options, therefore, tends to reduce the spending incurred on the other one. Mytelka (1987) found that external imports of technology discouraged Andean-group countries from undertaking in-house innovation activities. Fikkert (1993) regressed technology imports on in-house R\&D efforts and also found a negative relationship between technology imports and R\&D efforts in Indian manufacturing firms. Basant and Fikkert (1996) estimated the returns on $\mathrm{R} \& \mathrm{D}$, technology imports, and their interaction, using Indian firm-level panel data. They found substitutability between R\&D effort and external technology in the production of knowledge. Katrak (1997) found that the probability of importing technology is only weakly influenced by R\&D efforts, and Blonigen and Taylor (2000) also conclude that firms either make or buy technology.

Another group of studies concludes that in-house $R \& D$ and external technology purchasing are complementary strategies. According to the notion of absorptive capacity proposed by Cohen and Levinthal (1989), the successful use of external technology requires the ability to assimilate external technology and apply it internally. As suggested by Fu, Pietrobelli, and Soete (2010), a crucial condition for the effective transfer of technology to developing countries is their level of absorptive capacity. In this sense, parallel indigenous innovation efforts are complementary to international technology diffusion. The studies by Desai (1989), Lall (1989), and Mowery and Oxley (1995) confirm the view that technological capability is needed in order to understand the tacit components of foreign technology. Besides, acquiring technology externally helps to improve the efficiency of doing in-house R\&D. As Aggarwal (2000) points out, external technology sourcing plays two important roles in developing economies: filling gaps in domestic technological capability and upgrading the existing technologies to international standards. By enhancing technological capability, it may consequently stimulate in-house R\&D. Braga and Willmore (1991) found that there is a robust complementary relationship between technology buying and firms' technology efforts in Brazilian industry. Deolalikar and Evenson (1989) and Kim and Nelson (2000) come to the same conclusion on the basis of Indian data. A number of studies have tested a slightly different but related 
hypothesis based on data from developed countries, namely the existence of complementarity between internal and external R\&D: Arora and Gambardella (1990) for large US, European, and Japanese biotechnology firms, Cassiman and Veugelers (2006) and Veugelers (1997) for Belgian manufacturing firms, Bönte (2003) for West German industry data, and Belderbos et al. (2008) for Dutch firm data. Most of the studies share the view that internal and external R\&D are complementary, although Audretsch, Menkveld, and Thurik (1996) find that the complementarity applies only to high-technology industries.

\subsection{Country background}

China has been the fastest-growing major economy in the past 30 years, with an average annual GDP growth rate greater than 10 per cent. Around 8 per cent of the total manufacturing output in the world comes from China, and it ranks third worldwide in industrial output. ${ }^{4}$ The extraordinary performance of the Chinese economy makes it very interesting to study its technology-acquisition behaviour and to examine whether such acquisition contributed to the growth performance of its manufacturing firms.

In the 1950s, China began to acquire technology externally. At first, the major source of technology was the former Soviet Union. Then, western countries and Japan became the main suppliers of technology to heavy industry. After the economic open-door policy was launched in 1976, importing external technology constituted an essential component of the Four Modernisation Programmes (Zhao, 1995). Technology transfer became diversified through the purchase of turnkey plants and equipment, through foreign direct investment (FDI), and in the form of disembodied technology, including licensing, technical consulting, technical service, and co-production. Another feature is that the source of technology widened. Five countries - the USA, Japan, Germany, France, and the UK - dominated the supply of technology to China at that time. After the economic reforms of 1978, other industrial countries and regions, such as Canada, Italy, Taiwan, and Hong Kong, played an increasing role in providing technology to China (Zhang, 1990; Liu, 1992; Zhao, 1995). In 1985, the central government initiated the science and technology system reform, which defined the acquisition of foreign technology as one of the main technology-sourcing strategies for promoting technological development. After 1995, policies were designed to accelerate indigenous science and technology development by creating incentives and providing support for firms to establish $\mathrm{R} \& \mathrm{D}$ departments. As a result, these units increased dramatically, from 7,000 in 1987 to over 24,000 by 1998 (China Science and Technology Statistics, 1992, 1998), 5 and the R\&D expenditure grew annually by more than 20 per cent from 1995 to 2003 (OECD, 2006). However, when set against China's rapid economic

\footnotetext{
${ }^{4}$ For more detailed information the reader is referred to

http://en.wikipedia.org/wiki/Economy_of_the_People\%27s_Republic_of_China

5 Source: Ministry of Science and Technology of the People's Republic of China: http://www.most.gov.cn/eng/
} 
growth, its ratio of R\&D to GDP is still remarkably low (1.13 per cent in 2003) compared with the OECD countries $\left(2.25\right.$ per cent in 2003). ${ }^{6}$

The reform of Chinese state-owned enterprises (SOEs) was a critical part of establishing the indigenous innovation system. Unlike the private sector, with no government financial support since the reforms began in the 1980s, the SOEs have remained a persistent drain on government resources (Steinfeld, 1998; White, 2000). In order to encourage SOEs to introduce new products, rather than simply producing more of their existing products, the government introduced investment tax incentives (Rawski, 1994; White, 2000). Particularly since 1993, the innovation policy was sharply focused on reforming SOEs. Evidence has shown that SOEs became more strategic and dynamic in innovation in reacting to competitive pressures (Luo et al., 1998). Managers of SOEs were being granted greater responsibility and decision-making power (Child, 1994; Guthrie, 1997; Walder, 1989), especially for meeting profit-based and efficiency-based measures of performance (Groves et al., 1994; White and Liu, 1998).

Like other developing countries, China has two main objectives in acquiring foreign technology: to enhance technological capability and to facilitate economic growth by increasing productivity. It is interesting to examine these issues after China's transition to a market economy, a period during which it experienced unprecedented changes in its social, legal, and economic institutions (Zhou, Yim, and Tse, 2005). Table 1 presents some selected studies which analyse the relationship of internal and external technological sourcing in China. Although the external technology alone does not always have a significant impact on innovation, in general the findings confirmed the complementary relationship between in-house $R \& D$ and external technology sourcing (e.g. Liu and Buck, 2007; Liu and Zou, 2008; Bin, 2008; Li, 2011; Li and Wu, 2010).

Insert table 1 here

\section{Empirical model and testing of complementarity/substitutability}

\subsection{Definitions}

A pair of economic activities is complementary if (1) adopting one does not preclude adopting the other one, and (2) the sum of the benefits of implementing each activity separately is not greater[SHOULDN'T THIS BE LESS THAN TO BE CONSISTENT WITH THE FOLLOWING SENTENCE? Answer: we meant that the benefits of implementing both activities simultaneously are greater than the sum of implementing each activity SEPARATELY. The following sentence states that the return of implementing one activity is higher if the other activity is already implemented (implementing both activities simultaneously)] than the benefit of implementing both together. An equivalent understanding of the second

6 Main source: OECD library, http://www.oecd-ilibrary.org/economics/oecd-factbook-2005_factbook-2005-en 
condition is that the incremental return to implementing any one of the activities is greater if the other one is already implemented. A theorem states that if each pair of activities in a group is complementary, then implementing any subset of the activities in the group raises the incremental return to implementing the remaining ones (Topkis, 1978). Complementarity between activities in economic models was developed by Vives (1990) and Milgrom and Roberts (1990, 1995).

More formally, suppose there are two technology-acquisition practices, $R \& D$ and $T P$, and $Z$ is a vector of exogenous variables. If $\mathrm{R} \& \mathrm{D}$ and $\mathrm{TP}$ are discrete variables, they are complementary if the presence of one strategy (say, R\&D) increases the marginal return of adopting the other strategy (TP), controlling for other effects. In other words, the objective function $\mathrm{f}(\mathrm{R} \& \mathrm{D}, \mathrm{TP}, \mathrm{Z})$ is supermodular, meaning that the following inequality holds for all values of the other arguments of $\mathrm{f}($.$) (Milgrom and Roberts, 1990):$

$f(1,1 ; Z)-f(1,0 ; Z)>f(0,1 ; Z)-f(0,0 ; Z)$

If $R \& D$ and TP are continuous variables, this inequality restriction implies that the incremental effect on the objective function of increasing one practice increases conditionally on increasing another practice:

$\frac{\partial^{2} f(R, T, Z)}{\partial R \partial T}>0 \quad$; where R stands for R\&D and T for TP.

Conversely, R\&D and TP are substitutes if the inverse of inequality (1) or (2) holds.

Testing complementarity among activities in maximizing an objective function has been done in several empirical studies (Cassiman and Veugelers, 2006; Mohnen and Röller, 2003; Belderbos et al., 2008). This approach is known as the production function approach (PROD). It refers to a synergistic effect between activities which will lead to a better performance in terms of a stated goal. Another approach to test complementarity, known as the correlation approach (CORR), consists in checking the sign of the correlation coefficient between strategies conditional on certain other determinants. In Table 1, methods adopted in testing complementarity are shown in column 5. The current study will focus only on the PROD. We shall consider two kinds of performance objective: innovation output and total factor productivity (TFP). If there is complementarity between in-house R\&D and technology purchase, it can show up in greater innovation output and indirectly in higher TFP levels through the effect of innovation output on TFP. Given the way in which innovation output and TFP are measured, we have to resort to different econometric models to test complementarity with respect to each of these two objectives.

\subsection{Testing for complementarity in terms of innovation output}

Innovation output can refer to different kinds of innovation and can be measured in a qualitative or in a quantitative way. We shall consider two kinds of innovation output: new products and new processes. Based 
on the questionnaire, process innovation can be measured only by its incidence, whereas product innovation will be measured by its incidence and its intensity. Hence for process innovation we specify a probit model, i.e. we observe a dichotomous variable $\operatorname{Pr} O c_{i}$ which equals 1 when the firm claims to have introduced a new process in the period under review, and zero otherwise. The values one and zero correspond respectively to a positive and a negative value of a latent variable $\operatorname{Pr} o c_{i}^{*}$, which is itself determined by innovation inputs and firm-specific variables:

$\operatorname{Pr} o c_{i}^{*}=v_{b} I_{b i}+v_{m} I_{m i}+\delta_{b} I_{b i} \ln r_{b i}+\delta_{m} I_{m} \ln r_{m i}+\delta_{b m} I_{b i} \ln r_{b i} I_{m i} \ln r_{m i}+\varphi W_{i}^{*}+\eta_{i}$

where $r_{b, i}$ and $r_{m, i}$ are the levels of innovation inputs (TP and $\mathrm{R} \& \mathrm{D}$ respectively), expressed in expenditure per employee, so that a marginal effect of an increase in their levels depends on the size of the firm. ${ }^{7}$ It is unreasonable to assume that the marginal effect of 1,000 additional RMB spent on R\&D or TP would be the same for large and small firms. $W_{i}^{*}$ is a vector of exogenous variables that affect the probability of innovating. $\boldsymbol{v}_{b}, \boldsymbol{v}_{m}, \delta_{b}, \delta_{m}, \delta_{b m}$, and $\phi$ are coefficients to be estimated. $\boldsymbol{\eta}$ is a random error term due to measurement errors and omitted variables. Since R\&D and TP have many zeros (around 60 per cent for $\mathrm{R} \& \mathrm{D}$ and 80 per cent for TP), we model them first as dichotomous variables ( $\mathrm{I}_{\mathrm{bi}}=1$ if TP is different from zero, and $\mathrm{I}_{\mathrm{mi}}=1$ if $\mathrm{R} \& \mathrm{D}$ is different from zero, and zero otherwise) and, if they are both present, we allow for complementarity or substitutability between them in their continuous variations. If $\delta_{b m}$ is positive (negative) and statistically significant, then there is complementarity (substitutability) between R\&D and TP. Since there are only six cases ${ }^{8}$ where firms purchase technology without doing their own R\&D, we cannot reasonably identify any complementarity or substitutability with the discrete variables.

For product innovation, we observe, on the one hand, a dichotomous variable $\operatorname{Pr} o d_{i}$ equal to one if a new product has been introduced on the market and zero otherwise; and, on the other hand, a continuous variable Innosale $_{i}$, which measures the sales of new products per employee. Since this variable is measured only for firms that have introduced a new product on the market, OLS estimates would suffer from a potential selection bias. To correct for this bias, we shall specify a tobit type II model composed of a main equation of interest (3.2) and a selection equation (3.3):

$\ln \left(\right.$ Innosale $\left._{i}\right)=v_{b}^{o} I_{b i}+v_{m}^{o} I_{m i}+\delta_{b}^{o} I_{b i} \ln r_{b i}+\delta_{m}^{o} I_{m i} \ln r_{m, i}+\delta_{b m}^{o} I_{b i} \ln r_{b i} I_{m i} \ln r_{m i}+\varphi^{o} W_{i}+\eta_{i}^{o}$

\footnotetext{
${ }^{7}$ Index b refers to 'buy', i.e. technology purchases; index $\mathrm{m}$ refers to 'make', i.e. own R\&D.

8 Among these six cases, two are in the electronic equipment industry, two in the electronic parts-making industry, one in the garment and leather products industry, and one in the metallurgical products industry.
} 


$$
\begin{gathered}
\operatorname{Pr} o d_{i}^{*}=v_{b}^{*} I_{b i}+v_{m}^{*} I_{m i}+\delta_{b}^{*} I_{b i} \ln r_{b i}+\delta_{m}^{*} I_{m i} \ln r_{m i}+\delta_{b m}^{*} I_{b i} \ln r_{b i} I_{m i} \ln r_{m i}+\varphi W_{i}^{*}+\eta_{i}^{*}, \\
\left\{\begin{array}{l}
\operatorname{Pr} o d_{i}=1 \text { if } \operatorname{Pr} o d_{i}^{*}>0 ; \\
\operatorname{Pr} o d_{i}=0 \text { if } \operatorname{Pr} o d_{i}^{*} \leq 0
\end{array}\right.
\end{gathered}
$$

where $\operatorname{Pr} o d_{i}^{*}$ in the selection equation (3.3) is a latent variable which indicates if a firm had any product innovation or not in the period under review, depending on whether its value lies above the threshold zero or not. Innosale ${ }_{i}$ is only observed if $\operatorname{Pr} o d_{i}=1$. We assume that the error terms $\boldsymbol{\eta}_{i}^{o}$ and $\eta_{i}^{*}$ follow a joint normal distribution with $\operatorname{var}\left(\eta_{i}^{*}\right)=1, \operatorname{var}\left(\eta_{i}^{0}\right)=\sigma_{2}^{2}, \operatorname{cov}\left(\eta_{i}^{0}, \eta_{i}^{*}\right)=\rho \sigma_{2}$. In order to identify the effects of the explanatory variables $W_{i}$ and $W_{i}^{*}$, the latter will contain at least one extra exogenous variable not included in $W_{i}$. Due to the fact that the innovation-output indicator is only available for the year 2002, the probit model (3.1) and the generalized tobit model (3.2) and (3.3) will be estimated on cross-sectional data.

\subsection{Testing for complementarity in terms of total factor productivity}

In addition to looking at the effect of technology-sourcing strategies on innovation output, we will go one step further and also investigate whether there is a synergy between $\mathrm{R} \& \mathrm{D}$ and TP in promoting firms' productivity performance. We start from a general production function:

$Y_{i t}=g\left(T F P_{i t}\right) h\left(K_{i t}, L_{i t}, M_{i t}\right)+\varepsilon_{i t}$

where $Y_{\text {it }}$ stands for total sales, $K_{\mathrm{it}}, L_{\mathrm{it}}$, and $M_{\mathrm{it}}$ represent respectively the inputs physical capital, labour, and materials, $\mathrm{TFP}_{\text {it }}$ is the total factor productivity, which is driven by the innovation inputs, industry specifics, and ownership characteristics, and $\varepsilon_{\text {it }}$ is a random error term. Here we index all variables by subscripts $i$ for firms and $\mathrm{t}$ for time, because now we have panel data. TFP is supposed to be a function of the innovation inputs $r_{b, i t}$ (TP per employee) and $r_{m, i t}$ (R\&D expenditure per employee), other explanatory variables $V_{\text {it }}$ (ownership dummies, export dummies, and age of the firm), industry dummies $\left(\mathrm{I}_{i}\right)$ to capture differences in technological opportunities, and time dummies $\left(\mathrm{T}_{t}\right)$ to capture year-to-year fluctuations in productivity. We assume that the functions $\mathrm{g}($.$) and \mathrm{h}($.$) are separable, and that both are second-order approximations after a$ logarithmic transformation of (4).

After rewriting (4) in terms of labour productivity, so as to estimate directly the extent of scale economies, we obtain the labour-productivity function (5): 
$\ln \left(Y_{i t} / L_{i t}\right)=\gamma_{0}+\beta_{k} \ln \left(K_{i t} / L_{i t}\right)+\left(\beta_{l}+\beta_{k}+\beta_{m}-1\right) \ln L_{i t}+\beta_{m} \ln \left(M_{i t} / L_{i t}\right)$

$+0.5 \beta_{k k}\left(\ln \left(K_{i t} / L_{i t}\right)\right)^{2}+0.5 \beta_{m m}\left(\ln \left(M_{i t} / L_{i t}\right)\right)^{2}+\beta_{k m} \ln \left(K_{i t} / L_{i t}\right) \ln \left(M_{i t} / L_{i t}\right)$

$+I_{b i t}\left(\alpha_{b}+\gamma_{b} \ln r_{b i t}+0.5 \gamma_{b b}\left(\ln r_{b i t}\right)^{2}\right)+I_{m i t}\left(\alpha_{m}+\gamma_{m} \ln r_{m i t}+0.5 \gamma_{m m}\left(\ln r_{m i t}\right)^{2}\right)+I_{b i t} I_{m i t}\left(\alpha_{b m}+\gamma_{b m}\left(\ln r_{b i t}\right)\left(\ln r_{m i t}\right)\right)$

$+\gamma_{v} V_{i t}+\Sigma_{j} \gamma_{j} I_{j}+\Sigma_{t} \gamma_{t} T_{t}+\omega_{i}+\varepsilon_{i t}$

As in equations (3), we model the effects of $R \& D$ and TP first as a step function with different levels of TFP for the observations where R\&D or TP is present, and secondly in a continuous way only for the cases where both are present. In (5) we have expressed R\&D and TP in logarithms assuming constant elasticities. The disturbance term has two orthogonal components: the time-invariant individual effects $\omega_{i}$, which are unobserved by the econometrician but known to the firm (such as managerial ability or organizational ability), and the idiosyncratic productivity shocks $\varepsilon_{i t}$, which are unobserved by the econometrician and by the firm. We assume the idiosyncratic error term to be uncorrelated with past values of the explanatory variables.

The problem here is that the inputs, especially the traditional inputs - labour, capital, and materials - but also the innovation-related inputs $r_{b, i t}$ and $r_{m, i t}$, may be correlated with $\omega_{\mathrm{i}}$. The endogeneity of input practices makes OLS fail to generate consistent estimators. To tackle the endogeneity problem we use the system-GMM estimator (Arellano and Bond, 1991; Blundell and Bond, 1998). ${ }^{9}$ Taking the first differences of equation (5) will remove the unobserved individual effect $\omega_{i}$, thus eliminating a potential source of omitted variable bias in the estimation. Then, the differenced variables that are not strictly exogenous are instrumented with all their available lagged levels (Difference GMM). However, lagged levels are poor instruments for first differences if the variables are close to a random walk (Holtz-Eakin, Newey, and Rosen, 1988; Arellano and Bover, 1995). Therefore, Blundell and Bond (1998) suggest adding another set of orthogonality conditions, namely between the levels of the error term and the first-differences in the exogenous variables under the assumption of stationarity. This is the idea behind System GMM.

\section{Data and variables}

The data used in our empirical analysis are from the World Bank Investment Climate Survey (ICS) ${ }^{10}-$ China 2003. The survey is conducted in 24 industrial cities and provides us with a wide range of information about the economic environment and activities of the firms. The majority of firms included in the ICS China 2003

\footnotetext{
${ }^{9}$ We prefer to use the dynamic panel GMM approach rather than the proxy-based approach introduced by Olley and Pakes (1996). Ackerberg et al. (2006) compare the two approaches and discuss their respective advantages and disadvantages.

10 See footnote 3 .
} 
are of small or medium size. ${ }^{11}$ After removing missing values, cleaning for outliers and removing the largesize firms, we are left with 3,332 observations of small and medium-sized firms from 18 cities and 10 manufacturing industries for the period 2000 to $2002 .{ }^{12}$ Several aspects of firms' innovation activity are covered in the survey, such as the firms' innovative input strategies and innovation outputs. We deflate annual sales, profits, capital, materials, and innovation expenditure to convert them into values expressed in year-2000 prices. $^{13}$

\subsection{Variables in the innovation equation}

The dependent variable in the innovation equation (3.1) is a dichotomous variable equal to 1 if the firm claims to have had either a product or a process innovation in the years 2000 to 2002. In equation (3.2) the dependent variable is the log of sales of new products per employee. There are two categories of variable that might affect the probability of having a successful innovation and the intensity of innovative sales.

The first category captures firm specifics. With more profits in previous periods, firms have more cash available and are therefore more likely to invest in innovation and be successful innovators (Katrak, 1997). PROFIT per employee is the average ratio of profit (before tax) per employee from 2000 to 2002. CAPITAL per employee, which is the average capital/labour ratio from 2000 to 2002, serves as an indicator of the capital intensity, but it also to some extent reflects the size of a firm. Larger firms are expected to have more resources to allocate to innovation activities, which leads to better innovation performance. Company ownership can be a crucial variable in innovation performance in the case of China, as it affects the motivation to innovate and the continuity of business strategy. State-owned enterprises (SOEs) are usually reluctant to undertake changes. However, with investment and tax incentives from the government, they might have more resources to carry out innovation activities. So the effect of SOEs on innovation output is ambiguous. Foreign-controlled firms tend to concentrate their research and development in their home countries (OECD, 2003). A negative sign is expected. SOE and FOREIGN indicate respectively state and

\footnotetext{
11 According to the National Bureau of Statistics of China, small-sized firms have fewer than 300 employees, medium-sized firms have between 300 and 2,000 employees, and large-sized firms have more than 2,000 employees. The classification is based on the number of long-term employees according to 'The classification of small, medium and large Chinese manufacturing firms' from the National Bureau of Statistics of China: http://www.stats.gov.cn/. The large-sized firms included in the sample, after dropping missing values, represent about 3.5 per cent of the total sample (33 firms). We decided to drop these firms and look only at the small and medium-sized firms. Meanwhile, there are about 40 per cent of firms with fewer than 100 employees. It is interesting to look at their technology-sourcing behaviour separately, since the t-tests in Table 2 and Table 4 show that their characteristics are significantly differently from those of other firms. In total, our sample is divided into three categories: firms with fewer than 100 employees (40.1 per cent), firms with a number of employees between 100 and 300 (30.37 per cent), and firms with more than 300 employees (29.53 per cent).

12 Firms with no information on financial outcomes are omitted. The service sector is not included, because the innovation outputs are not reported. Furthermore, following Hall and Mairesse (1995), we keep observations only for cases in which the capital-labour ratio is within three times the inter-quartile range (the difference between the 75 per cent value and the 25 per cent value) above or below the median. This removed 129 observations, or 2.1 per cent of the sample. The remaining sample is an unbalanced panel with 3,332 observations for the period 2000 to 2002.

13 For the annual sales and profits, we use the wholesale-price deflators at the industry level. For capital, material, and innovation expenditure, the industry-input deflators are used (Chinese Bureau of Statistics, 2000-2003).
} 
foreign ownership. The dummy EXPORT indicates if firms have positive exports in 2002. On the one hand, the point of learning-by-exporting suggests that technology flows from international buyers help to improve the performance of exporters (Salmon and Shaver, 2005; Liu and Zou, 2008). Furthermore, fierce competition on the international market stimulates firms to be innovative. On the other hand, especially in the case of China, exporting firms compete successfully in the international market by relying on the price advantage of already-existing products due to the relatively low material and labour costs. This might inhibit innovation, especially product innovation. So the sign of EXPORT is ambiguous. AGE is calculated as the number of years evolved since the enterprise started production, up to 2002. Young firms are expected to be more dynamic and innovative, all other things equal (Katrak, 1997), and therefore a negative effect is expected. Innovation activities tend to be relatively more intensive in the technologically more advanced industries, such as pharmaceuticals, electrical equipment, and electronics. Industry specifics are controlled for by industry dummies.

The second category of explanatory variables is the set of innovation inputs. The survey contains information on two technology-sourcing strategies. Firms are asked to report their annual in-house R\&D expenditure. In-house R\&D spending comprises capital, labour, and design costs associated with research and development. The other way for firms to increase their technological expertise is to buy technology directly from external channels, on the domestic or the international market. Technology purchasing is defined in the questionnaire as the amount that firms spend on purchasing technology externally. The two variables are respectively denoted by R\&D and TP. Both are measured in average spending per employee in 2000-2002. More investment in in-house R\&D and external technology purchasing will strengthen the firms' technological capability and contribute to raising their innovation output. We expect both marginal effects to have a positive sign. The sign of the interaction term of R\&D and TP indicates their complementarity or substitutability. Dummy variables R\&D_PRI, R\&D_UNI, and R\&D_FIRM are equal to 1 if firms have any R\&D co-operation with public research institutes, universities, or other firms. The Chinese government has strongly encouraged Public Research Institutes (PRIs) and universities to create more effective links with industry since the 1980s. In 2004, about one-third of large and medium-sized companies' R\&D spending went to universities and PRIs as contracted R\&D (National Bureau of Statistics of China, 2006). We use these three variables as proxies for technological opportunity. Any form of cooperation constitutes an information source for new technologies and could lead to innovativeness. The benefits drawn from co-operative activities might only show up in the probability of innovation but not in new product sales, since most of the innovations carried out in universities and research institutes focus on basic science research that will not be immediately commercialized in the market.

Additional variables are included in the selection equation (3.3) in order to avoid identification problems. These variables are expected to influence the occurrence of product innovation, but not the intensity. In 
reality, such variables are difficult to define (Puhani, 2000; Vella, 1998). City dummies will be used here as proxies for the location of a firm. In China, being located in a developed industrial city (such as in the coastal area) may provide firms with greater policy-oriented opportunities to undertake innovation activities. However, location may not affect the intensity of innovation, which depends rather on variables reflecting the market structure (as shown by Sasidharan and Kathuria, 2011).

\subsection{Variables in the production function}

In the production function, the dependent variable is PRODUCTIVITY. It is measured in sales per employee. The three conventional inputs are CAPITAL, measured as the total book value of fixed assets, LABOUR, measured as the number of full-time employees, and MATERIAL, measured as the costs of raw materials and energy and other related costs reported by the firm. ${ }^{14}$ The innovation inputs R\&D and TP and their interaction will also enter the productivity equation as endogenous variables. We control for several variables (FOREIGN, SOE, and EXPORT) that capture the firms' competitiveness and technological capability. Foreign-owned firms are characterized by higher capital intensity, high quality of human capital, and efficient management. Many previous studies suggest that foreign-owned firms are more productive (Globerman et al., 1994; Doms and Jensen, 1998; Kimura and Kiyota, 2007). State-owned enterprises (SOEs) are usually characterized by redundant workers and inefficient management. As we can see from Table 2, SOEs are mostly medium-sized firms (hence above the sample average with respect to the number of employees), while their productivity is below the sample average. They are not motivated to perform efficiently, because the local government takes full responsibility for their production and profit. For this reason, we expect SOEs to have a negative effect on the productivity performance. EXPORT activities are expected to enhance economic growth and improve the productivity of involved firms (Beckerman, 1962; Bhagwati, 1988). Firms participating in international markets are exposed to more intense competition. More vigorous competition exerts discipline on firms. It therefore tends to strengthen their efficiency, and we expect a positive effect. We also control for industry and year specifics by using industry and year dummies.

\subsection{Descriptive statistics}

Tables 2 to 4 provide descriptive statistics on the conventional inputs, the productivity performance, the technology sourcing, and the control variables across industries. As Table 2 shows, high-tech industries such as electronic equipment, household electronics, and biotechnology have a higher capital/labour ratio, are more productive, and more active in collaborative research. Enterprises in household electronics and garments are more likely to sell their products abroad and to be foreign-owned. Firms with fewer than 100 employees are on average younger, less collaborative in research, less capital-intensive, less often foreign- or

\footnotetext{
14 The capital and material inputs are logarithmically transformed and expressed in 1,000 RMB per employee.
} 
state-owned, less export-oriented, and less productive. Table 3 provides the descriptive statistics across industries for SOEs. Except for the transportation-equipment industry, SOEs have lower labourproductivity level than the other firms in the corresponding industry, confirming the OECD (2007) report. In contrast, SOEs are more capital-intensive and bigger (in terms of number of employees). They are more numerous in electronic parts, auto parts, metallurgical products, and the garment industry. They are less likely to export, and their average age is 28 years, which is almost twice the average age of the whole sample. They are more likely to collaborate in research. Notice that almost half of the SOEs in the biotechnological industry claim to have $\mathrm{R} \& \mathrm{D}$ co-operation with public research institutions.

\section{Insert tables 2 and 3 here}

Table 4 presents the innovation outputs and inputs of Chinese small and medium-sized manufacturing firms. Approximately 46 per cent of the firms claim to have introduced a new product, and 25 per cent have introduced a new process in the period under review. Technology-intensive industries such as electronics and biotech are more likely to be innovators, and they also perform better in terms of new product sales, as shown by column four in Table 4. It should be noted that the product and process innovations in developing countries are not conventionally defined as new to the market, but rather as new to the firm. It has been postulated that new and dynamic industries in developing countries can most readily catch up (Gerschenkron, 1962). Under the R\&D, TP, R\&D, and TP headings we report the observed incidences ${ }^{15}$ and corresponding expenditure statistics. As is shown in Table 4, the electronic equipment, auto and auto parts, and biotech industries spend more on technology acquisition, both internally and externally, than traditional industries such as chemicals, garment and leather, and food processing. The relatively lower innovation efforts might explain why most Chinese firms in low-tech industries have not been able to catch up with technological advances, as argued by Fu and Gong (2010).

\section{Insert table 4 bere}

The lack of efficiency of Chinese SOEs is also shown in the innovation input and output data. The proportion of firms that do in-house R\&D is higher for SOEs than for the total sample, and the same goes for technology purchasing. As a result, the innovation propensities in terms of products and processes are above the overall averages. However, the intensities of R\&D and TP expenditures per employee are lower for SOEs than for the overall sample; and the average value of new product sales per employee, which takes into account the relative level and the market success of innovation, is substantially below the overall sample average. A similar pattern holds in terms of firm size. Enterprises with fewer than 100 employees are lower in terms of engaging in $\mathrm{R} \& \mathrm{D}$ and $\mathrm{TP}$ and introducing new products and processes, but higher in terms of

15 The percentage of firms that claimed to have positive expenditures of R\&D and TP in the period under review. 
$\mathrm{R} \& \mathrm{D}$, TP, and product-innovation intensities compared with other two groups (firms with 100 to 300 employees and firms with more than 300 employees).

\section{Empirical results}

We now turn to the results of the econometric analysis regarding how the two technology-sourcing strategies, R\&D and TP, affect the innovation and productivity performances of small and medium-sized Chinese manufacturing firms, and the question of whether they are substitutes or complements. We have divided the sample into three groups: the set of firms with fewer than 100 employees (very small-sized firms), the set of those with more than 100 and fewer than 300 employees (small-sized firms), and the set of those with more than 300 employees (medium-sized firms), because there are some clear differences between the three groups.

\subsection{The role of $R \& D$ and TP in stimulating innovation}

Table 5 presents the marginal effects of the regressors in the Probit model (equation 3.1) and the tobit type II model (equations (3.2) and (3.3)). The observed frequencies of R\&D performers and technology purchasers are 42 per cent and 18 per cent respectively, and only six firms which bought knowledge from outside did not perform their own R\&D. We had difficulties identifying a separate intercept for firms with their own R\&D and external technology purchases and therefore did not introduce the interaction of the two dummies in the model.

\section{Insert table 5 bere}

In Table 5 we report the marginal effects of the explanatory variables for the probit regression for process innovation and the selection equation for product innovation and the marginal effects on the unconditional expected value of new product sales per employee. In Appendix A we derive the marginal effects of the regressors on the conditional (equation 7) and unconditional expectations of new product sales per employee (equations (10)-(14)). When computing the marginal effects of dummy $\mathrm{I}_{\mathrm{b}}$ or $\mathrm{I}_{\mathrm{m}}$, we take into account all the terms where these two dummies appear (i.e. four terms in total). For $I_{m} \ln (R \& D / l a b o u r)$ and $\mathrm{I}_{\mathrm{b}} \ln (\mathrm{TP} /$ labour$)$, we include in the computation of the elasticities of square term and the interaction term. The marginal effects of $I_{m} \ln (R \& D / \text { labour })^{2} / 2$ and $I_{b} \ln (T P / \text { labour })^{2} / 2$ represent second-order derivatives, and the marginal effect of $\mathrm{I}_{\mathrm{m}} \ln (\mathrm{R} \& \mathrm{D} /$ labour $) * \mathrm{I}_{\mathrm{b}} \ln (\mathrm{TP} /$ labour $)$ represents the second-order cross derivative of the unconditional expectation of new product sales/employee. Standard errors are computed using the 
Delta method. ${ }^{16}$

$\mathrm{R} \& \mathrm{D}$ is found to have a significant positive effect on process innovation only for firms with more than 300 employees. Firms that do R\&D have a 21.3 percentage-point higher incidence of process innovation than those that do no R\&D (coefficient of $\mathrm{I}_{\mathrm{m}}$ ). ${ }^{17}$ Our data do not allow us to conclude anything regarding the marginal effect of a quantitative increase in $R \& D$ on process innovation, except for small firms where a 10 per cent increase in R\&D per employee increases the probability of innovating by 0.7 percentage points. Technology purchasing has a negative and significant effect on process innovation, again only in a certain sized class, this time medium-sized firms: technology-purchasing firms have there on average a 15.8 percentage-point lower incidence of process innovation than non-technology-purchasing firms. For all other firms we cannot conclude anything about how TP affects process innovation. Our two sources of technology have a clearer effect on product innovation. In very small firms (fewer than 100 employees), R\&D performing firms have a 22.5 percentage-point higher probability of being product innovators and 43.9 per cent higher sales of new products per employee than non-R\&D-performing firms. In medium-sized firms the incidence is 35.7 percentage points higher, and the sales of new products per employee are 54 per cent higher for R\&D firms than for non-R\&D firms. In small firms (between 100 and 300 employees), these magnitudes are not precisely estimated, but the new-product sales elasticity with respect to R\&D is 0.404 . Technology purchasing has also a positive effect on product innovation. In very small firms, TP firms have on average a 26.6 per cent higher sales figure per employee than non-TP firms; small TP firms are on average 32.4 percentage points more likely to innovate in products than are non-TP firms; and their sales per employee are 86.1 per cent higher - a figure which, however, declines by 2.1 per cent as TP expenditure per employee increases by 10 per cent (coefficient of $\mathrm{I}_{\mathrm{b}} \ln \left(\mathrm{TP} /\right.$ labour)); ${ }^{18}$ and finally in medium-sized firms new product sales per employee rise by 3.8 per cent as TP per employee increases by 10 per cent. The only significant sign of complementarity between R\&D and TP is visible for small firms, where the elasticity of new product sales per employee with respect to R\&D increases by 0.22 per cent as technology purchasing increases by 10 per cent. ${ }^{19}$ The synergy between own R\&D and external technology purchasing, at least as it is evident in small Chinese manufacturing firms (between 100 and 300 employees), is in line with the argument of absorptive capacity (Cohen and Levinthal, 1990) and the results reported by Li and Wu (2010), Liu and White (1997), Liu and Buck (2007), and Liu and Zou (2008).

Among the control variables, characteristics such as being an exporter, a young firm, a foreign-owned firm,

16 The Delta method is based on the first order approximation around the mean. For more details, see Oehlert (1992).

17 When computing the marginal effects of Ib or Im, we take into account all the terms where these two dummies appear (i.e. four terms in total).

18 When computing the marginal effects of $\operatorname{Im} \ln (\mathrm{R} \& \mathrm{D} /$ labour) and $\mathrm{Ibln}(\mathrm{TP} /$ labour), the elasticities of the square term $\left(\operatorname{Im} \ln (\mathrm{R} \& \mathrm{D} / \text { labour })^{2} / 2\right.$ and $\left.\mathrm{Ib} \ln (\mathrm{TP} / \text { labour })^{2} / 2\right)$ and the interaction term $(\mathrm{Im} \ln (\mathrm{R} \& \mathrm{D} /$ labour $) * \mathrm{Ibln}(\mathrm{TP} /$ labour $)$ ) are also accounted. 19 As Ai and Norton (2003) pointed out, complementarity should be based on a positive sign of the cross-elasticity and not the interaction term alone. 
or a firm that co-operates in R\&D positively affect the probability or the intensity of innovating. Exporting firms with 100 to 300 and more than 300 employees have a 16 and 14 percentage-point higher probability of process innovation. Old firms are expected to be less dynamic and innovative (Katrak, 1997). Indeed, they have 1.2 to 2.7 percentage-point lower sales of new products per employee in very small and small-sized firms. Foreign-owned firms with fewer than 100 employees have a 30 percentage-point higher productinnovation intensity. Due to the high costs and uncertainties connected with innovation, firms with profits are more likely to have the adequate financial resources to innovate. An increase of 1,000 RMB in profit per employee increases by 0.3 percentage points the sales of new products per employee for firms with fewer than 100 employees and by 1.7 and 1.8 percentage points for small and medium-sized firms. State-owned enterprises have a 21 percentage-point higher probability of innovating in processes if they have more than 300 employees. They probably benefit from greater financial and policy support from government. R\&D collaborations with other firms, public research institutes, and universities increase the probability of innovation and the intensity of product innovations especially for the very small firms (see Boeing, Mueller, and Sandner, 2012). Those with fewer than 100 employees that benefit from any kind of R\&D collaboration have 60 percentage-point higher sales of new products per employee. For firms with 100 to 300 employees, it is mostly collaborations with other firms and universities that affect the innovation intensity, increasing it by 59.6 and 53.5 percentage points. Collaborations with universities seem to decrease sales of new products per employee by 36.3 per cent in medium-sized firms.

\subsection{The role of $R \& D$ and TP in promoting productivity}

We now go a step further and examine the issue of complementarity or substitutability between in-house $\mathrm{R} \& \mathrm{D}$ and technology purchasing in terms of achieving a better productivity performance, since in the end innovation serves to improve productivity. Table 6 presents the results of the productivity equation (5) obtained using ordinary least squares (OLS) and the system GMM method. The system GMM exploits the orthogonality conditions between the first differences in the error term and the explanatory variables in levels lagged by one period, once for 2002 and once for 2001, and the orthogonality conditions between the error terms in levels and the lagged first differences of the explanatory variables. Hence in total there are 85 orthogonality conditions, 29 estimated coefficients, and consequently 56 overidentifying restrictions. ${ }^{20}$ The

\footnotetext{
20 The number of orthogonality conditions equals the number of instruments used for the endogenous variables plus the number of pre-determined variables (used as their own instruments). In the GMM case, 14 variables are considered to be endogenous (the first 14 independent variables in the table). We consider the first differences in the error term of the productivity equation to be orthogonal to the one- and two-period lagged levels of the endogenous variables for the year 2002 and to the one-period lagged levels of the endogenous variables for the year 2001 (remember, we have no data prior to 2000). That makes 42 orthogonality conditions so far. As to the level of the error term, we consider it to be orthogonal to the first differences in the endogenous variables for 2002 and for 2001. That makes 28 additional orthogonality conditions (14 for each year). So, in total the system GMM exploits 70 orthogonality conditions to instrument for the endogenous variables, plus 15 orthogonality conditions using the predetermined variables of our model (the time, industry, ownership and exporting status dummies) in the first difference equations, which makes a grand total of 85 orthogonality conditions. The number 56 in the Hansen overidentification test equals the total number of orthogonality conditions (85) minus the number of estimated parameters (29).
} 
OLS estimates are likely to be inconsistent, because of the endogeneity of the conventional inputs and the innovation-strategy variables. They are only shown as a benchmark. In the presence of a positive productivity shock, we expect firms to increase their inputs, but the existence of adjustment costs for labour and capital will have them increase materials more than the two quasi-fixed inputs. Hence we would expect an upward bias in the estimate of the output elasticity of the inputs, more for materials than for labour and capital. $R \& D$ is probably more quasi-fixed than technology purchases, and hence we expect a stronger upward bias for the latter than for the former. The directions of bias are partly confirmed by our estimates. Yet the OLS estimates are not very different from the GMM estimates, which is a sign that the latter are not unreasonable. Our interpretation will be based on the system GMM estimation, which tackles the endogeneity problem. The instruments used in the GMM estimation are acceptable by the Hansen test of overidentifying restrictions, which is only significantly different from zero at a p-value of 38 (resp. 16) per cent for firms with fewer (resp. more) than 100 employees. The Difference-in-Hansen test also accepts the 28 additional orthogonality conditions of the level equations that differentiate the System GMM from the First-difference GMM estimates. ${ }^{21}$

\section{Insert table 6 bere}

We have chosen a translog approximation to a general production function in the conventional inputs (the $h($.$) function in equation (4)) as well as a translog approximation of the total factor productivity expression in$ the two technology variables (the $\mathrm{g}($.$) function in equation (4)). We have normalized the conventional inputs,$ capital and material, and the technology inputs, R\&D and TP, by labour and introduced a separate labour term to capture the departure from constant returns to scale with respect to all the inputs. ${ }^{22}$ The point of approximation is around unit values of the input/output ratios, which is out of the sample for the conventional inputs (see Table 2) but quite reasonable for the technology inputs (see Table 4). We have also accounted for the fact that many firms have no R\&D or no technology purchase by including dummy indicators for these two variables and by interacting these dummy variables with their respective amounts when they are positive.

We cannot reject the null hypothesis of constant returns to scale (the $\ln$ (labour) coefficient is not significantly different from 0). Capital and material are substitutes. We report the output elasticities of physical capital, materials, R\&D, and TP evaluated at the means of the variables. ${ }^{23}$ The elasticities for capital

\footnotetext{
21 The two-step system GMM performed in STATA 11, using the xtabond2 command, automatically corrects the standard errors for heteroskedasticity and autocorrelation (Roodman, 2006).

${ }^{22}$ By dividing all the inputs by labour and dividing output by labour, we have imposed that the second-order parameters of the translog approximation sum up to zero and the first-order terms sum up to 1 , so as to impose constant returns to scale. We have then allowed the sum of the first-order terms to deviate from 1 by allowing for a labour first-order term to appear on the right-hand side.

23 When the marginal effects were computed, we include the elasticities of the square term and the interaction term. See footnotes
} 
are quite reasonable, around .08 to .18 for capital and .53 to .62 for material.

The results in Table 6 show that firms with in-house R\&D/employee at its mean value and no TP have a 29 (resp. 18 per cent) higher labour productivity than firms with no R\&D in the small (resp. medium-sized firms) and no significant difference in labour productivity for very small firms (coefficients of $I_{m}$ ). In contrast, the effect of technology purchases is visible mainly in very small firms and small firms, but not in medium-sized firms. With technology purchases are at their mean value and no R\&D, very small (resp. small) firms have a 69 (resp. 39) per cent higher labour productivity than firms with no technology purchasing. Medium-sized firms show no significant difference in labour productivity between TP and nonTP firms. For firms that do both R\&D and TP, labour productivity is significantly lower than for firms that do neither of them. In this sense, the two means of knowledge accumulation are at odds with each other. Since their respective effect on innovation (product and process) is generally positive, the average negative effect on labour productivity for firms that pursue both strategies must be due to some excessive cost, a possible duplication of knowledge acquisition, or some correlation of those activities with other associated characteristics, such as lack of experience or age of the firm. For instance, one could imagine that young, non-technology-based firms, are less efficient because they lack know-how or technological capabilities, which they try to acquire by all possible means from inside or outside the firm.

The elasticity of output with respect to R\&D (for R\&D-performing firms) shows significance only for small firms, where we obtain an elasticity of 0.11 , which is quite consistent with the elasticities reported in the literature (see Hall, Mairesse, Mohnen, 2010). The elasticity of output with respect to TP (for firms with TP) is significant at 0.10 (coefficient of $\mathrm{I}_{\mathrm{b}} \ln (\mathrm{TP} /$ labour)) in medium-sized firms and not significant elsewhere. A complementarity between $R \& D$ and TP actually shows up in very small firms (coefficient of $I_{b m}$ $\ln (\mathrm{R} \& \mathrm{D} /$ labour $) \ln (\mathrm{TP} /$ labour $)$, while in the other firms the cross-elasticity of output with respect to $\mathrm{R} \& \mathrm{D}$ and TP is not significant. This means that in very small firms the returns from investing in one source of knowledge, R\&D or technology purchasing, increase with the investment in the other source. In that sense the two strategies are complements. As for the control variables, the results are not surprising. In China, the majority of foreign-invested firms are in the high-tech industry and in general characterized by the higher average technical efficiency compared with domestic firms (Fu and Gong, 2010). As expected, foreignowned firms are more productive than the reference category of firms in terms of ownership structure, i.e. domestic, non-state-owned firms. In contrast to foreign firms, SOEs tend to be less productive compared with firms with other ownership structures. This evidence reflects the inefficiency of Chinese SOEs. This finding is consistent with studies in other developing countries (Braga and Willmore, 1991). Exporting firms in China, at least those with more than 300 employees, are more productive than non-exporting firms. This

17 and 18. For computing the marginal effects of $\ln ($ capital/labour) and $\ln$ (material/labour), the square term and the interaction term are also included. 
may indicate that the pressure on international markets enables firms to foster their productivity, or that the higher productivity enables firms to export.

We must be cautious when we compare our results with others in the literature. Hu et al. (2005) found complementarity between domestic R\&D and technology transfer. But their results are based on large and medium-sized Chinese enterprises which probably involve a different pattern of innovation-sourcing strategies. Bönte (2003) and Belderbos et al. (2008) showed complementarity between internal (i.e. in-house) and external (i.e. contracted-out) $\mathrm{R} \& \mathrm{D}$ in West Germany and the Netherlands respectively. But our study is not comparable to theirs, because our measure of purchased technology relates to the purchase of existing technology, from domestic or foreign sources, and not to the execution of R\&D outside of the firm's R\&D facilities. We investigate the complementarity not between between ways of performing R\&D but between $\mathrm{R} \& \mathrm{D}$ and the purchase of existing technology. Fikkert (1993) and Basant and Fikkert (1996) found substitutability between R\&D and TP for Indian firms, but that was in a regime where there were controls on the external sourcing of technology, whereas in the period that we are examining Chinese firms were actually encouraged to import technology. ${ }^{24}$

\section{Conclusion}

This paper explores the impact of internal and external technology sourcing on firms' innovation and productivity performance in Chinese small- and medium-sized manufacturing firms. In particular, it investigates the returns of R\&D and external technology purchasing (TP) and their possible complementarity or substitutability. It does so by distinguishing two performance measures: innovation in products or processes and labour productivity. Since size may matter in this regard, we estimate separately the relationships for firms with fewer than 100, between 100 and 300, and more than 300 employees.

Do Chinese firms need both R\&D and TP in order to grow and catch up with technological advances? Our evidence suggests (1) that firms with R\&D are more innovative; (2) that firms with TP are (with the exception of process innovations in medium-sized firms) more innovative than non-TP firms; (3) that the elasticities or semi-elasticities of process or product innovation with respect to R\&D and TP are positive whenever they are significant (with the exception of TP on product-innovation intensity in small firms); (4) that the output elasticities of $R \& D$ and TP are always positive whenever they are significant, and of a reasonable order of magnitude (around 0.10); and (5) that, whenever there are significant estimates, a complementarity exists between R\&D and TP in promoting innovation or labour productivity.

External technology purchasing complements internal R\&D in fostering innovation and labour productivity. To the extent that firms might not be sufficiently informed of this synergy in technology acquisition, it

24 We thank an anonymous referee for this remark. 
might be useful for the Chinese government to promote the adoption of both sources of technology acquisition. The somewhat surprising result is that firms that do both do not necessarily have the highest productivity performance. The exact reasons for this phenomenon, which could be duplication in knowledge acquisition, short-term adjustment costs, or other characteristics of those particular firms, would be worth exploring further.

Appendix A Calculating the marginal effects of explanatory variables on the unconditional expectation of new products sales per employee

The conditional expected value of $y_{2}$ is:

$\mathrm{E}\left(\mathrm{y}_{2} \mid \mathrm{y}_{1}^{*}>0\right)=\beta_{2}^{\prime} \mathrm{x}_{2}+\mathrm{E}\left(\varepsilon_{2} \mid \varepsilon_{1}>-\beta_{1}^{\prime} \mathrm{x}_{1}\right)=\beta_{2}^{\prime} \mathrm{x}_{2}+\varrho \sigma_{2} \frac{\phi\left(\beta_{1}^{\prime} \mathrm{x}_{1}\right)}{\Phi\left(\beta_{1}^{\prime} \mathrm{x}_{1}\right)}$

$\mathrm{E}\left(\mathrm{y}_{2} \mid \mathrm{y}_{1}=1\right)=\beta_{2}^{\prime} \mathrm{X}_{2}+\mathrm{E}\left(\varepsilon_{2} \mid \varepsilon_{1}>-\beta_{1}^{\prime} \mathrm{X}_{1}\right)=\beta_{2}^{\prime} \mathrm{X}_{2}+\varrho \sigma_{2} \frac{\phi\left(\beta_{1}^{\prime} \mathrm{X}_{1}\right)}{\Phi\left(\beta_{1}^{\prime} \mathrm{X}_{1}\right)}$

Using the inverse Mills Ratio $\lambda(\mathrm{a})=\frac{\phi(a)}{1-\Phi(a)}=\frac{\phi(-a)}{\Phi(-a)}=\frac{\phi\left(\beta_{1}^{\prime} X_{1}\right)}{\Phi\left(\beta_{1}^{\prime} X_{1}\right)}$

where $a=\frac{-\beta_{1}^{\prime} X_{1}-E\left(\varepsilon_{1}\right)}{\sigma_{1}}=-\beta_{1}^{\prime} X_{1}$

$\phi$ and $\Phi$ are, respectively, the normal density function and the normal distribution function, $y_{2}$ represents new product sales per employee (innosale $\mathrm{i}_{\mathrm{i}}$ ), $\mathrm{X}_{\mathrm{i}}$ are the regressors of equation $\mathrm{i}$ where $\mathrm{i}=1,2$ (index 1 refers to the selection equation (3.3) and index 2 to the intensity equation (3.2)), we can rewrite the conditional expected value of $y_{2}$ is:

$\mathrm{E}\left(\mathrm{y}_{2} \mid \mathrm{y}_{1}^{*}>1\right)=\beta_{2}^{\prime} \mathrm{X}_{2}+\mathrm{E}\left(\varepsilon_{2} \mid \varepsilon_{1}>-\beta_{1}^{\prime} \mathrm{X}_{1}\right)=\beta_{2}^{\prime} \mathrm{X}_{2}+\varrho \sigma_{2} \lambda(a)$

The conditional marginal effects:

$$
\begin{aligned}
& \frac{\partial \mathrm{E}\left(\mathrm{y}_{2} \mid \mathrm{y}_{1}^{*}>1\right)}{\partial \mathrm{x}_{\mathrm{i}}}=\beta_{2 \mathrm{i}}+\varrho \sigma_{2} \frac{\partial}{\partial \mathrm{a}}\left[\frac{\phi(a)}{1-\Phi(a)}\right] \frac{\partial(a)}{\partial \mathrm{x}_{\mathrm{i}}}=\beta_{2 \mathrm{i}}-\varrho \sigma_{2} \beta_{1 \mathrm{i}} \frac{\phi^{\prime}(a)[1-\Phi(a)]+[\phi(a)]^{2}}{[1-\Phi(a)]^{2}} \\
& \phi^{\prime}(a)=-(a) * \phi(a) \\
& \lambda(a)^{\prime}=-\beta_{1 j} \lambda(a)[\lambda(a)-a] \\
& \frac{\partial E\left(y_{2} \mid y_{1}^{*}>0\right)}{\partial x_{i}}=\beta_{2 i}-\varrho \sigma_{2}\left(\beta_{1 i}\right)\left\{\frac{[\phi(a)]^{2}}{[1-\Phi(a)]^{2}}-\frac{(a) * \phi(a) *[1-\Phi(a)]}{[1-\Phi(a)]^{2}}\right\} \\
& =\beta_{2 i}-\varrho \sigma_{2}\left(\beta_{1 i}\right) \frac{\phi(-a)}{\Phi(-a)}\left[\frac{\phi(-a)}{\Phi(-a)}-a\right] \\
& =\beta_{2 i}-\varrho \sigma_{2} \beta_{1 i} \lambda(a)[\lambda(a)-a]
\end{aligned}
$$

This is the marginal effect of $x_{i}$ on the conditional expected value of $y_{2}$. Here, we are considering only the effect of $x_{i}$ on the value of $y_{2}$ for those having product innovation. Notice that the conditional marginal effect in (7) depends on the vector $X_{1}$, since $a=-\beta_{1}^{\prime} X_{1}$. In general, the conditional marginal effect of a 
variable $\mathrm{X}_{\mathrm{i}}$ will be different for each observation (individual). We shall evaluate it at the means of the observations for each variable.

The unconditional expected value of new product sales per employee is given by:

$E\left(y_{2} \mid X\right)=\mathrm{E}\left(\varepsilon_{2} \mid \varepsilon_{1}>-\beta_{1}^{\prime} X_{1}\right) \Phi\left(\beta_{1}^{\prime} X_{1}\right)+\mathrm{E}\left(\varepsilon_{2} \mid \varepsilon_{1}<-\beta_{1}^{\prime} X_{1}\right) \Phi\left(-\beta_{1}^{\prime} X_{1}\right)$

Since y $2=0$ if a firm has no product innovation: $\varepsilon_{1}<-\beta_{1}^{\prime} X_{1}$. Then (8) can be written as

$E\left(y_{2}\right)=\mathrm{E}\left(\varepsilon_{2} \mid \varepsilon_{1}>-\beta_{1}^{\prime} X_{1}\right) \Phi\left(\beta_{1}^{\prime} X_{1}\right)$

The unconditional effect is:

$\frac{\partial \mathrm{E}\left(\mathrm{y}_{2}\right)}{\partial \mathrm{x}_{\mathrm{i}}}=\Phi\left(\beta_{1}^{\prime} \mathrm{X}_{1}\right) \frac{\partial\left(\mathrm{y}_{2} \mid \mathrm{y}_{1}^{*}>1\right)}{\partial \mathrm{x}_{\mathrm{i}}}+\beta_{1 \mathrm{i}} \mathrm{E}\left(\varepsilon_{2} \mid \varepsilon_{1}>-\beta_{1}^{\prime} \mathrm{X}_{1}\right) \phi\left(\beta_{1}^{\prime} \mathrm{X}_{1}\right)$
$=\Phi\left(\beta_{1}^{\prime} X_{1}\right)\left\{\beta_{2 i}-\varrho \sigma_{2} \beta_{1 i} \lambda(a)[\lambda(a)-a]\right\}+\beta_{1 i}\left[\beta_{2}^{\prime} X_{2}+\varrho \sigma_{2} \lambda(a)\right] \phi\left(\beta_{1}^{\prime} X_{1}\right)$

Following (10), the second-order derivative with respect to $x_{j}$ is

$$
\begin{aligned}
& \frac{\partial^{2} E\left(y_{2}\right)}{\partial x_{i} \partial x_{j}}=\phi\left(\beta_{1}^{\prime} X_{1}\right) * \beta_{1 j} *\left\{\beta_{2 i}-\varrho \sigma_{2} \beta_{1 i} \lambda(a)[\lambda(a)-a]\right\}-\Phi\left(\beta_{1}^{\prime} X_{1}\right) * \varrho \sigma_{2} \beta_{1 i} W \\
& +\beta_{1 i}\left\{\left[\beta_{2}^{\prime} X_{2}+\varrho \sigma_{2} \lambda(a)\right] *\left[-\beta_{1}^{\prime} X_{1} * \phi\left(\beta_{1}^{\prime} X_{1}\right) * \beta_{1 j}\right]+\phi\left(\beta_{1}^{\prime} X_{1}\right) * Q\right\}
\end{aligned}
$$

where

$$
\begin{aligned}
W & =\left[\lambda(a)^{2}-\lambda(a) * a\right]^{\prime}=2 \lambda(a) * \lambda(a)^{\prime}-\left[\lambda(a)^{\prime} * a+a^{\prime} * \lambda(a)\right] \\
& =2 \lambda(a) *\left\{\beta_{1 j} \lambda(a)[a-\lambda(a)]\right\}-\left\{\beta_{1 j} \lambda(a)[a-\lambda(a)] * a-\beta_{1 j} \lambda(a)\right\} \\
& =2 \beta_{1 j} \lambda(a)^{2}[a-\lambda(a)]-\beta_{1 j} \lambda(a)\{[a-\lambda(a)] * a-1\} \\
\mathrm{Q} & =\left[\beta_{2}^{\prime} X_{2}+\varrho \sigma_{2} \lambda(a)\right]^{\prime}=\beta_{2 j}+\varrho \sigma_{2} \beta_{1 j} \lambda(a)[a-\lambda(a)] .
\end{aligned}
$$




\section{References}

Ackerberg, D., Caves, K. and Frazer, G. (2006) 'Structural Identification of Production Functions, mimeo.

Aggarwal, A. (2000) 'Deregulation, technology imports and in-house R\&D efforts: an analysis of the Indian experience', Research Policy, 29: 1081-1093.

Ai, C. and Norton, E. (2003) 'Interaction terms in logit and probit models', Economics Letters, 80: 123-9.

Arellano, M. and Bond, S. (1991) 'Some tests of specification for panel data: Monte Carlo evidence and an application to employment equations', Review of Economic Studies, 58: 277-97.

Arellano, M. and Bover, O. (1995) 'Another Look at the Instrumental Variable Estimation of Error Component Models', Journal of Econometrics, 68: 29-51.

Arora, A. and Gambardella, A. (1990) 'Complementarity and external linkages: the strategies of the large firms in biotechnology', Journal of Industrial Economics, 38: 361-79.

Audretsch, D., Menkveld, A. and Thurik, R. (1996) 'The decision between internal and external R\&D', Journal of Institutional and Theoretical Economics, 152: 519-30.

Basant, R. and Fikkert, B. (1996) 'The effects of R\&D, foreign technology purchase, and domestic and international spillovers on productivity in Indian firms', Review of Economics and Statistics, 78(2): 187-99.

Beckerman, W. (1962) ‘Projecting Europe’s growth’, Economic Journal, 72: 912-25.

Belderbos R., Lokshin, B. and Carree, M. (2008) 'The productivity effects of internal and external R\&D: evidence from a dynamic panel data model', Oxford Bulletin of Economics and Statistics, 70(3): 399-413.

Bhagwati, J. N. (1988) 'Export-promoting trade strategy: issues and evidence', The World Bank Research Observer, 3(1): 27-57.

Bin, G. (2008) 'Technology acquisition channels and industry performance: an industry-level analysis of Chinese large- and medium-size manufacturing enterprises', Research Policy, 37: 194-209.

Blundell, R. and Bond, S. (1998) 'Initial conditions and moment restrictions in dynamic panel data models', Journal of Econometrics, 87: 115-43.

Blonigen, B. and Taylor, C. (2000) 'R\&D intensity and acquisitions in high-technology industries: evidence from the U.S. electronic and electrical equipment industries', Journal of Industrial Economics, 48: 47-70.

Boeing, F., Muelle, E. and Sandner, P. (2012) 'What Makes Chinese Firms Productive? - Learning from Indigenous and Foreign Sources of Knowledge.' Mimeo.

Bönte, W. (2003) 'R\&D and productivity: internal vs. external R\&D - evidence from West-German manufacturing industries', Economics of Innovation and New Technology, 12: 343-60.

Braga, H. and Willmore, L. (1991) 'Technology imports and technological efforts: an analysis of the determinants in Brazilian firms', The Journal of Industrial Economics, 39: 421-37.

Cassiman, B. and Veugelers, R. (2006) 'In search of complementarity in the innovation strategy: internal R\&D and external knowledge acquisition', Management Science, 52: 68-82.

Child, J. (1994) Management in China during the Age of Reform, Cambridge, England: Cambridge University Press.

Cohen, W. and Levinthal, D. (1989) 'Innovation and learning: the two faces of R\&D', The Economic Journal, 99: 569-96.

Desai, A.V. (1989) Indian Technology Imports from SMEs, New Delhi: National Council for Applied Economic Research. 
Deolalikar, A.B. and Evenson, R.E. (1989) 'Technology production and technology purchase in Indian industry and econometric analysis', Review of Economics and Statistics, 71(4): 687-92.

Doms, M. and Jensen, J.B. (1998) 'Comparing wages, skills and productivity between domestically and foreignowned manufacturing establishments in the United States', in R.E. Baldwin, R.E. Lipsey, and J.D. Richardson (eds), Geography and Ownerships as Basis for Economic Accounting, Chicago: University of Chicago Press.

Fikkert, B. (1993) 'An Open or Closed Technology Policy? The Effects of Technology Licensing, Foreign Direct Investment and Technology Spillovers on R\&D in Indian Industrial Sectors' Firms', unpublished PhD dissertation, New Haven, CT: Yale University.

$\mathrm{Fu}, \mathrm{X}$. and Gong, Y. (2010) 'Indigenous and foreign innovation efforts and drivers of technological upgrading: evidence from China', World Development, 39(7): 1213-25.

$\mathrm{Fu}, \mathrm{X}$., Pietrobelli, C. and Soete, L. (2010) 'The role of foreign technology and indigenous innovation in the emerging economies: technological change and catching-up', World Development, 39(7): 1204-12.

Gerschenkron, A. (1962) Economic Backwardness in Historical Perspective, a Book of Essays, Cambridge, MA: Belknap Press of Harvard University Press.

Globerman, S., Ries, J. and Vertinsky, I. (1994) 'The economic performance of foreign affiliates in Canada', Canadian Journal of Economics, 27: 143-56.

Groves, T., Hong, Y., McMillan, J. and Naughton, B. (1994) 'Autonomy and incentives in Chinese state enterprises', Quarterly Journal of Economics, 109: 183-209.

Guthrie, D. (1997) 'Between markets and politics: organizational responses to reform in China', American Journal of Sociology, 102: 1258-1304.

Hall, B. H. and Mairesse, J. (1995) 'Exploring the relationship between R\&D and productivity in French manufacturing firms', Journal of Econometrics, 65(1): 263-93.

Hall, B.H., Mairesse, J. and Mohnen, P. (2010) 'Measuring the returns to R\&D', in B. H. Hall and N. Rosenberg (eds), Handbook of the Economics of Innovation, Amsterdam: Elsevier, 1034-82.

Holtz-Eakin, D., Newey, W. and Rosen, H. (1988) 'Estimating Vector Autoregressions with Panel Data', Econometrica, 56(6): 1371-95.

Hu, A., Jefferson G. and Qian, J. (2005) 'R\&D and technology transfer: firm-level evidence from Chinese industry', Review of Economics and Statistics, 87(4): 780-6.

Katrak, H. (1997) 'Developing countries' imports of technology, in-house technologies capabilities and efforts: an analysis of the Indian experience', Journal of Development Economics, 53: 67-83.

Kim, L. and Nelson, R. (2000) Technology, Learning and Innovation: Experiences of Newly Industrializing Economies, Cambridge: Cambridge University Press.

Kimura, F. and Kiyota, K. (2007) 'Foreign-owned versus domestically-owned firms: economic performance in Japan', Review of Development Economics, 11: 31-48.

Lall, S. (1989) Learning to Industrialise: The Acquisition of Technological Capability by India, London: Macmillan.

Li, X. (2011) 'Sources of external technology, absorptive capacity, and innovation capability in Chinese StateOwned High-Tech enterprises', Wold Development, 39 (7): 1240-8.

Li, X. and Wu, G. (2010) 'In-house R\&D, technology purchase and innovation: empirical evidences from Chinese hi-tech industries, 1995-2004', International Journal of Technology Management, 51(2/3/4): 217-38.

Liu, H. (1992) 'A summary of technical trade of China in 1990', Almanac of Foreign Economic Relations in China, 5582. 
Liu, X. and Buck, T. (2007) 'Innovation performance and channels for international technology spillovers: evidence from Chinese high-tech industries', Research Policy, 36: 355-66.

Liu, X. and White, R. (1997) 'The relative contributions of foreign technology and domestic inputs to innovation in Chinese manufacturing industries', Technovation, 17(3): 119-25.

Liu, X. and Zou, H. (2008) 'The Impact of Greenfield FDI and Mergers and Acquisitions on Innovation in Chinese High-tech Industries', Journal of World Business, 43: 352-64.

Lu, Q. and Lazonick, W. (2001) 'The organization of innovation in a transitional economy: business and government in Chinese electronic publishing', Research Policy, 30: 55-77.

Luo, Y., Tan, J. and Shenkar, O. (1998) 'Strategic responses to competitive pressure: the case of township and village enterprises in China', Asia Pacific Journal of Management, 15: 33-50.

Milgrom, P. and Roberts, J. (1990) 'The economics of modern manufacturing: technology, strategy, and organization', American Economic Review, 80: 511-28.

Milgrom, P. and Roberts, J. (1995) 'Complementarities and fit strategy, structure and organizational change in manufacturing', Journal of Accounting and Economics, 19: 179-208.

Mohnen, P. and Röller, L.-H. (2005) 'Complementarities in innovation policy', European Economic Review, 49: 1431-50.

Mowery, D. and Oxley, J. (1995) 'Inward technology transfer and competitiveness: The role of national innovation systems', Cambridge Journal of Economics, 19: 67-93.

Mytelka, L.K. (1987) 'Licensing and technology dependence in the Andean group', World Development 6(4): 44759.

National Bureau of Statistics of China (2006) The China Statistic Yearbook (2006)

http://www.stats.gov.cn/english/

OECD (2003) Towards a Knowledge-based Economy, Paris: OECD.

OECD (2006) Main Science and Technology Indicators, Paris: OECD.

OECD (2007) Reviews of Innovation Policy China, http://www.oecd.org/publishing/corrigenda.

Oehlert, G. W (1992) 'A note on the delta method', American Statistician 46: 27-9.

Olley, S. and Pakes, A. (1996) 'The dynamics of productivity in the telecommunications equipment industry', Econometrica, 64: 1263-98.

Puhani, P.A. (2000) 'The Heckman correction for sample selection and its critique', Journal of Economic Surveys, 14: 53-68.

Rawski, T. (1994) 'Chinese industrial reform: accomplishments, prospects and implications', American Economic Association Papers and Proceedings, 84: 271-5.

Roodman, D. (2006) 'How to do xtabond2: an introduction to "Difference" and "System" GMM in Stata', Centre for Global Development Working Paper Number 103.

Salmon, R. and Shaver, J. (2005) 'Learning by Exporting: New Insights from Examining Firm Innovation', Journal of Economics and Management Strategy, 14: 431-60.

Sasidharan, S. and Kathuria, V. (2011) 'Foreign direct investment and R\&D: substitute or complements: a case of Indian manufacturing after 1991 reforms', World Development, 39(7): 1226-39.

Steinfeld, E. (1998) Forging Reform in China: The Fate of State-Owned Industry, Cambridge: Cambridge University Press.

Topkis, D. M. (1978) 'Minimizing a submodular function on a lattice', Operations Research, 26: 305-21. 
Vella, F. (1998) 'Estimating models with sample selection bias: a survey', Journal of Human Resources 33: 127-72. Veugelers, R. (1997) 'Internal R\&D expenditures and external technology sourcing', Research Policy, 26(3): 303-15. Vives, X. (1990) 'Nash Equilibrium with strategic complementarities', Journal of Mathematical Economics, 19(2): 20519.

Walder, A. G. (2003) 'Elite Opportunity in Transition Economies’, American Sociological Review, 68: 899-916.

White, S. (2000) 'Competition, capabilities, and the make, buy, or ally decisions of Chinese state-owned firms', Academy of Management Journal, 43 (3): 324-41.

White, S. and Liu, X. (1998) 'Organizational processes to meet new performance criteria: Chinese pharmaceutical firms in transition', Research Policy, 27: 369-83.

Zhang, X. (1990) 'Survey of technology import and export in China', Almanac of Foreign Economic Relations in China, 54-78.

Zhao, H. (1995) 'Technology imports and their impacts on the enhancement of China's indigenous technological capability', The Journal of Development Studies, 31(4): 585-602.

Zhou K. Z., Yim, C. K. and Tse, D. K. (2005) 'The effects of strategic orientations on technology- and market based breakthrough innovations', Journal of Marketing, 69(2): 42-60. 
Table 1 Literature on complementarity in technology sourcing in China

\begin{tabular}{|c|c|c|c|c|c|}
\hline Study by & Data & $\begin{array}{l}\text { Dependent } \\
\text { variables }\end{array}$ & $\begin{array}{l}\text { Technology } \\
\text { sourcing }\end{array}$ & Method 25 & Findings \\
\hline Zhao, 1995 & $\begin{array}{l}\text { Heavy industries, firm- } \\
\text { level data, 1960-1991 }\end{array}$ & $\begin{array}{l}\text { Output; } \\
\text { export value }\end{array}$ & $\begin{array}{l}\text { R\&D and technical } \\
\text { upgrading }\end{array}$ & CORR & $\begin{array}{l}\text { Imported technology } \\
\text { complements R\&D }\end{array}$ \\
\hline $\begin{array}{l}\text { Liu and White, } \\
1997\end{array}$ & $\begin{array}{l}\text { Industry-level data, } \\
\text { 1987-1993 }\end{array}$ & $\begin{array}{l}\text { New } \\
\text { product } \\
\text { sales }\end{array}$ & $\begin{array}{l}\text { R\&D personnel } \\
\text { and technology } \\
\text { imports }\end{array}$ & $\begin{array}{l}\text { PROD } \\
\text { OLS }\end{array}$ & $\begin{array}{l}\text { R\&D complements } \\
\text { technology transfer }\end{array}$ \\
\hline Hu et al., 2005 & $\begin{array}{l}\text { Large and medium- } \\
\text { sized enterprises, } \\
\text { 1995-1999 }\end{array}$ & $\begin{array}{l}\text { Produc- } \\
\text { tivity }\end{array}$ & $\begin{array}{l}\text { R\&D, technology } \\
\text { transfer, and FDI }\end{array}$ & $\begin{array}{l}\text { PROD } \\
\text { IV }\end{array}$ & $\begin{array}{l}\text { R\&D complements } \\
\text { technology transfer }\end{array}$ \\
\hline $\begin{array}{l}\text { Liu and Buck, } \\
\text { 2007; Liu and } \\
\text { Zou, } 2008\end{array}$ & $\begin{array}{l}\text { High-tech industry, } \\
\text { with annual turnover } \\
\text { above } 5 \text { million RMB, } \\
\text { 1997-2002 }\end{array}$ & $\begin{array}{l}\text { New } \\
\text { product } \\
\text { sales }\end{array}$ & $\begin{array}{l}\text { Foreign R\&D and } \\
\text { domestic R\&D }\end{array}$ & $\begin{array}{l}\text { PROD } \\
\text { GMM }\end{array}$ & $\begin{array}{l}\text { Domestic R\&D } \\
\text { complements foreign } \\
\text { R\&D }\end{array}$ \\
\hline Bin, 2008 & $\begin{array}{l}\text { Large and medium- } \\
\text { sized manufacturing } \\
\text { enterprises, } \\
\text { 1996-2001 }\end{array}$ & $\begin{array}{l}\text { Labour } \\
\text { produc- } \\
\text { tivity and } \\
\text { number of } \\
\text { patents }\end{array}$ & $\begin{array}{l}\text { In-house R\&D, } \\
\text { foreign transfer, } \\
\text { domestic transfer, } \\
\text { and inter-industry } \\
\text { R\&D spillovers }\end{array}$ & $\begin{array}{l}\text { PROD } \\
\text { FE, RE }\end{array}$ & $\begin{array}{l}\text { In-house R\&D } \\
\text { complements inter- } \\
\text { industry R\&D spillover } \\
\text { and foreign transfer }\end{array}$ \\
\hline Li, 2011 & $\begin{array}{l}\text { Large and medium- } \\
\text { sized SOEs in high- } \\
\text { tech industry, } \\
\text { 1995-2004 }\end{array}$ & $\begin{array}{l}\text { Number of } \\
\text { patents }\end{array}$ & $\begin{array}{l}\text { R\&D, domestic } \\
\text { technology, and } \\
\text { foreign technology }\end{array}$ & $\begin{array}{l}\text { PROD } \\
\text { Negative } \\
\text { binomial }\end{array}$ & $\begin{array}{l}\text { Foreign technology } \\
\text { complements R\&D }\end{array}$ \\
\hline $\begin{array}{l}\mathrm{Li} \text { and } \mathrm{Wu}, \\
2010\end{array}$ & $\begin{array}{l}\text { Large and medium- } \\
\text { sized firms in } 4 \text { high- } \\
\text { tech industries, } \\
\text { 1995-2004 }\end{array}$ & $\begin{array}{l}\text { Number of } \\
\text { patents }\end{array}$ & $\begin{array}{l}\text { R\&D, domestic } \\
\text { technology, and } \\
\text { foreign technology }\end{array}$ & $\begin{array}{l}\text { PROD } \\
\text { Negative } \\
\text { binomial }\end{array}$ & $\begin{array}{l}\text { Foreign technology } \\
\text { complements R\&D }\end{array}$ \\
\hline
\end{tabular}

25 For the methods of testing complementarity, see section 3.2. 
Table 2 Firm averages across industries (full sample)

\begin{tabular}{|c|c|c|c|c|c|c|c|c|c|c|c|c|}
\hline Industry & $\begin{array}{l}\text { N. } \\
\text { obs }\end{array}$ & $\begin{array}{c}\text { Producti } \\
\text { vity }\end{array}$ & Capital & Material & Labor & $\begin{array}{c}\text { SOE } \\
\text { dummy }\end{array}$ & $\begin{array}{l}\text { Foreign } \\
\text { dummy }\end{array}$ & $\begin{array}{l}\text { Export } \\
\text { dummy }\end{array}$ & Age & $\begin{array}{l}\mathrm{R}_{\mathrm{N}} \mathrm{D}_{-} \\
\mathrm{UNI}\end{array}$ & $\begin{array}{c}\text { R\&D_ } \\
\text { PRI }\end{array}$ & $\begin{array}{l}\text { R\&D } \\
\text { FIRM }\end{array}$ \\
\hline $\begin{array}{l}\text { Garment \& } \\
\text { leather }\end{array}$ & 778 & 3.871 & 3.091 & 3.059 & 4.953 & 0.090 & 0.193 & 0.391 & 12.772 & 0.042 & 0.035 & 0.063 \\
\hline $\begin{array}{l}\text { Electronic } \\
\text { equipment }\end{array}$ & 375 & 5.044 & 3.851 & 4.080 & 4.957 & 0.200 & 0.224 & 0.195 & 9.523 & 0.237 & 0.187 & 0.205 \\
\hline Electronic parts & 614 & 4.210 & 3.690 & 3.321 & 4.860 & 0.259 & 0.137 & 0.176 & 16.614 & 0.155 & 0.137 & 0.164 \\
\hline $\begin{array}{l}\text { Household } \\
\text { electronics } \\
\text { Auto \& auto }\end{array}$ & 128 & 4.525 & 3.825 & 3.273 & 5.216 & 0.047 & 0.367 & 0.445 & 11.461 & 0.172 & 0.102 & 0.188 \\
\hline parts & 734 & 4.344 & 3.716 & 3.560 & 5.261 & 0.228 & 0.113 & 0.108 & 16.634 & 0.082 & 0.105 & 0.178 \\
\hline $\begin{array}{l}\text { processing } \\
\text { Chemical }\end{array}$ & 144 & 4.483 & 3.624 & 3.603 & 4.898 & 0.250 & 0.146 & 0.069 & 15.708 & 0.188 & 0.181 & 0.125 \\
\hline products & 134 & 4.287 & 3.935 & 2.980 & 4.865 & 0.261 & 0.045 & 0.104 & 14.985 & 0.082 & 0.194 & 0.157 \\
\hline $\begin{array}{l}\text { Biotech } \\
\text { products } \\
\text { Metallurgical }\end{array}$ & 60 & 4.764 & 4.106 & 2.986 & 4.901 & 0.200 & 0.050 & 0.067 & 11.400 & 0.417 & 0.417 & 0.133 \\
\hline $\begin{array}{l}\text { products } \\
\text { Transportation }\end{array}$ & 327 & 3.601 & 3.534 & 2.601 & 4.765 & 0.312 & 0.092 & 0.064 & 17.294 & 0.055 & 0.086 & 0.150 \\
\hline equipment & 38 & 3.100 & 2.565 & 1.887 & 4.216 & 0.237 & 0.079 & 0.000 & 11.816 & 0.000 & 0.000 & 0.132 \\
\hline SOE firms ${ }^{26}$ & 671 & 3.845 & 4.066 & 2.901 & 5.666 & 1.000 & 0.000 & 0.107 & 28.261 & 0.142 & 0.137 & 0.168 \\
\hline Non-SOEs & 2661 & 4.313 & 3.439 & 3.402 & 4.808 & 0.000 & 0.171 & 0.225 & 11.079 & 0.107 & 0.107 & 0.139 \\
\hline $\begin{array}{l}\text { Employees } \\
<100 \\
\text { Employees }\end{array}$ & 1304 & 3.972 & 3.215 & 3.097 & 3.743 & 0.112 & 0.079 & 0.080 & 10.888 & 0.080 & 0.070 & 0.110 \\
\hline $00 \&<300$ & 1026 & 4.361 & 3.533 & 3.455 & 5.126 & 0.151 & 0.188 & 0.252 & 12.901 & 0.112 & 0.110 & 0.148 \\
\hline $\begin{array}{l}\text { Employees } \\
>=300\end{array}$ & 1002 & 4.393 & 4.054 & 3.409 & 6.443 & 0.369 & 0.215 & 0.306 & 20.967 & 0.161 & 0.172 & 0.187 \\
\hline Total & 3332 & 4.219 & 3.565 & 3.301 & 4.981 & 0.201 & 0.153 & 0.201 & 14.539 & 0.114 & 0.113 & 0.145 \\
\hline
\end{tabular}

Notes: Productivity is in logarithm of sales (in $1000 \mathrm{RMB}$ ) per employee.

Capital and material are also logarithmically transformed and in 1000RMB/employee.

Labour is the logarithm of the number of employees in the firm.

R\&D_UNI: dummy variable $=1$ if a firm reports co-operation with universities.

R\&D_PRI: dummy variable $=1$ if a firm reports co-operation with public research institutes.

R\&D_FIRM: dummy variable $=1$ if a firm reports co-operation with other firms.

26 t-tests have been used to test the differences in means between SOEs and non-SOEs for our main variables. The differences are significant (at 90 per cent level) for all variables in Table 2 except for R\&D_UNI, R\&D_RES and R\&D_FIRM. Similar t-tests have been conducted to compare the means of main variables for different-sized classes. The differences are always significant (at 90 per cent level) for firms with fewer than 100 and those with between 100 and 300 employees. For firms with 100 to 300 and above 300 employees, the only two variables where the differences are not significant at 90 per cent level are MATERIAL and R\&D_UNI. 
Table 3 Firm averages across industries (for SOEs)

\begin{tabular}{lcccccccccc}
\hline & & & & & & Export & & R\&D_ \\
Industry & N. obs & Productivity & Capital & Material & Labor & $\begin{array}{c}\text { R\&D } \\
\text { dummy }\end{array}$ & $\begin{array}{c}\text { Rge } \\
\text { FIRM }\end{array}$ \\
\hline $\begin{array}{l}\text { Garment \& } \\
\text { leather }\end{array}$ & 70 & 3.376 & 3.814 & 2.439 & 5.141 & 0.257 & 26.014 & 0.029 & 0.029 & 0.057 \\
$\begin{array}{l}\text { Electronic } \\
\text { equipment }\end{array}$ & 75 & 4.513 & 3.833 & 3.578 & 5.456 & 0.120 & 18.600 & 0.280 & 0.267 & 0.240 \\
$\begin{array}{l}\text { Electronic } \\
\text { parts }\end{array}$ & 159 & 3.808 & 4.094 & 2.823 & 5.520 & 0.164 & 28.843 & 0.189 & 0.214 & 0.257 \\
$\begin{array}{l}\text { Household } \\
\text { electronics }\end{array}$ & 6 & 2.383 & 4.717 & 1.762 & 6.159 & 0.000 & 3.000 & 0.000 & 0.000 & 0.000 \\
$\begin{array}{l}\text { Auto \& auto } \\
\text { parts }\end{array}$ & 167 & 4.068 & 4.351 & 3.312 & 6.258 & 0.072 & 33.413 & 0.126 & 0.072 & 0.137 \\
$\begin{array}{l}\text { Food } \\
\text { processing }\end{array}$ & 36 & 3.818 & 4.176 & 2.851 & 5.181 & 0.000 & 35.833 & 0.083 & 0.028 & 0.083 \\
$\begin{array}{l}\text { Chemical } \\
\text { products }\end{array}$ & 35 & 3.964 & 4.168 & 2.911 & 5.541 & 0.114 & 24.971 & 0.029 & 0.057 & 0.228 \\
$\begin{array}{l}\text { Biotech } \\
\text { products }\end{array}$ & 12 & 4.034 & 4.351 & 2.832 & 5.438 & 0.000 & 31.500 & 0.333 & 0.500 & 0.083 \\
$\begin{array}{l}\text { Metallurgical } \\
\text { products }\end{array}$ & 102 & 3.459 & 3.758 & 2.413 & 5.684 & 0.029 & 27.676 & 0.127 & 0.147 & 0.117 \\
$\begin{array}{l}\text { Transportation } \\
\text { equipment }\end{array}$ & 9 & 3.225 & 3.970 & 1.138 & 5.285 & 0.000 & 22.000 & 0.000 & 0.000 & 0.333 \\
\hline \begin{tabular}{l} 
Total \\
\hline
\end{tabular} & 671 & 3.845 & 4.066 & 2.901 & 5.666 & 0.107 & 28.261 & 0.142 & 0.137 & 0.168 \\
\hline
\end{tabular}

Notes: Productivity is in logarithm of sales (in $1000 \mathrm{RMB}$ ) per employee.

Capital and material are also in logarithmically transformed and in 1000RMB/employee.

Labour is the logarithm of the number of employees in the firm.

R\&D_UNI: dummy variable $=1$ if a firm reports co-operation with universities.

R\&D_PRI: dummy variable $=1$ if a firm reports co-operation with public research institutes.

R\&D_FIRM: dummy variable $=1$ if a firm reports co-operation with other firms. 
Table 4 Descriptive statistics of innovation inputs and outputs across industries (mean values in 2002)

\begin{tabular}{|c|c|c|c|c|c|c|c|c|c|c|}
\hline \multirow{2}{*}{\multicolumn{2}{|c|}{ Industry }} & \multicolumn{2}{|c|}{ Innovation } & \multirow{2}{*}{$\begin{array}{c}\text { New product } \\
\text { sales per } \\
\text { employee }\end{array}$} & \multicolumn{2}{|c|}{$\mathrm{R} \& \mathrm{D}$} & \multicolumn{2}{|c|}{$\mathrm{TP}$} & \multicolumn{2}{|c|}{ R\&D \&TP } \\
\hline & & Products & Process & & $\begin{array}{l}\text { Inci- } \\
\text { dence }\end{array}$ & $\begin{array}{c}\text { Expen- } \\
\text { diture }\end{array}$ & $\begin{array}{l}\text { Inci- } \\
\text { dence }\end{array}$ & $\begin{array}{c}\text { Expen- } \\
\text { diture }\end{array}$ & $\begin{array}{l}\text { Inci- } \\
\text { dence }\end{array}$ & $\begin{array}{r}\text { Expen } \\
\text { diture }\end{array}$ \\
\hline Garment \& leather & & 0.246 & 0.123 & 2.344 & 0.264 & -0.186 & 0.078 & -0.180 & 0.074 & 0.256 \\
\hline Electronic equipment & & 0.643 & 0.384 & 3.123 & 0.616 & 0.746 & 0.256 & -0.001 & 0.240 & 0.749 \\
\hline Electronic parts & & 0.542 & 0.316 & 2.116 & 0.485 & 0.196 & 0.223 & 0.000 & 0.214 & 0.362 \\
\hline Household electronics & & 0.648 & 0.438 & 2.625 & 0.581 & -0.031 & 0.256 & -0.042 & 0.256 & 1.212 \\
\hline Auto \& auto parts & & 0.527 & 0.260 & 2.151 & 0.482 & 0.079 & 0.215 & -0.167 & 0.215 & 0.655 \\
\hline Food processing & & 0.553 & 0.261 & 2.420 & 0.396 & -0.233 & 0.229 & -0.210 & 0.229 & 0.341 \\
\hline Chemical products & & 0.425 & 0.224 & 1.365 & 0.304 & 0.005 & 0.217 & -0.089 & 0.217 & 0.245 \\
\hline Biotech products & & 0.700 & 0.222 & 2.407 & 0.600 & 0.693 & 0.350 & 0.288 & 0.350 & 1.039 \\
\hline Metallurgical products & & 0.385 & 0.220 & 1.530 & 0.312 & -0.072 & 0.128 & -0.199 & 0.119 & 0.443 \\
\hline $\begin{array}{l}\text { Transportation } \\
\text { equipment }\end{array}$ & & 0.143 & 0.086 & 0.424 & 0.154 & 0.484 & 0.077 & 0.031 & 0.077 & 0.030 \\
\hline SOE firms $s^{27}$ & & 0.563 & 0.328 & 1.294 & 0.485 & -0.142 & 0.203 & -0.247 & 0.194 & 0.440 \\
\hline Non-SOEs & & 0.440 & 0.231 & 2.761 & 0.405 & 0.155 & 0.179 & -0.071 & 0.175 & 0.502 \\
\hline Employees $<100$ & & 0.353 & 0.194 & 2.970 & 0.278 & 0.143 & 0.106 & 0.005 & 0.101 & 0.229 \\
\hline $\begin{array}{l}\text { Employees }>=100 \\
<300 \\
\text { Employees }\end{array}$ & $\&$ & 0.476 & 0.242 & 2.852 & 0.411 & 0.103 & 0.192 & -0.094 & 0.183 & 0.557 \\
\hline$>=300$ & & 0.608 & 0.331 & 1.635 & 0.614 & 0.024 & 0.275 & -0.262 & 0.272 & 0.753 \\
\hline Total & & 0.464 & 0.251 & 2.278 & 0.422 & 0.094 & 0.184 & -0.107 & 0.178 & 0.489 \\
\hline
\end{tabular}

Note: Innovation (products/process): dummy variable equal to 1 if a firm has introduced a new product (process) in the period of 2000 to 2002.

New product sales: sales of new product per employee, in logarithms.

$\mathrm{R} \& \mathrm{D}$ expenditure (RD) and technology purchases (TP) are expressed in $1000 \mathrm{RMB}$ per employee, in logs;

$R \& D \& T P$ is the product of $R \& D$ and TP.

The means for R\&D, TP, and R\&D*TP are only taken for positive values of R\&D and/or TP.

\footnotetext{
27 t-tests have been used to test the differences in means between SOEs and non-SOEs for our main variables. The differences are significant (at 90 per cent level) for all variables in Table 2 except for TP. Similar t-tests have been conducted to compare the means of main variables for different-sized classes. The differences are always significant (at 90 per cent level) for firms with 100 to 300 and above 300 employees. For firms with fewer than 100 and those between 100 and 300 employees, the only variable where the differences are not significant at 90 per cent level is PROCESS.
} 
Table 5 Estimation results of innovation output (probit for process innovation, tobit type II for product innovation), marginal effects

\begin{tabular}{|c|c|c|c|c|c|c|c|c|c|}
\hline \multirow{3}{*}{ VARIABLES } & \multicolumn{3}{|c|}{$<100$ employees } & \multicolumn{3}{|c|}{$>=100 \&<300$ employees } & \multicolumn{3}{|c|}{$>=300$ employees } \\
\hline & \multirow{2}{*}{$\begin{array}{c}\text { Probit } \\
\text { Process } \\
\text { innovat. } \\
\text { Dummy }\end{array}$} & \multicolumn{2}{|c|}{ Tobit type II } & \multirow{2}{*}{$\begin{array}{c}\text { Probit } \\
\text { Process } \\
\text { innovat. } \\
\text { Dummy }\end{array}$} & \multicolumn{2}{|c|}{ Tobit type II } & \multirow{2}{*}{$\begin{array}{c}\text { Probit } \\
\text { Process } \\
\text { innovat. } \\
\text { Dummy } \\
\end{array}$} & \multicolumn{2}{|c|}{ Tobit type II } \\
\hline & & $\begin{array}{c}\text { New } \\
\text { product } \\
\text { sales/person }\end{array}$ & $\begin{array}{l}\text { Product } \\
\text { innovat. } \\
\text { Dummy }\end{array}$ & & $\begin{array}{l}\text { New product } \\
\text { sales/person }\end{array}$ & $\begin{array}{l}\text { Product } \\
\text { innovat. } \\
\text { Dummy }\end{array}$ & & $\begin{array}{l}\text { New product } \\
\text { sales/person }\end{array}$ & $\begin{array}{l}\text { Product } \\
\text { innovat. } \\
\text { Dummy }\end{array}$ \\
\hline & $(1)$ & $(2)$ & (3) & (4) & (5) & $(6)$ & $(7)$ & (8) & (9) \\
\hline \multirow[t]{2}{*}{$\mathbf{I}_{\mathrm{m}}$} & 0.108 & $0.439 * * *$ & $0.225^{* * *}$ & -0.058 & $0.404^{* *}$ & 0.138 & $0.213 * * *$ & $0.540^{* *}$ & $0.357 * * *$ \\
\hline & $(0.068)$ & $(0.127)$ & $(0.083)$ & $(0.071)$ & $(0.177)$ & $(0.090)$ & $(0.067)$ & $(0.266)$ & $(0.079)$ \\
\hline \multirow[t]{2}{*}{$\mathbf{I}_{\mathbf{b}}$} & -0.013 & $0.266^{*}$ & -0.047 & 0.028 & $0.861 * * *$ & $0.324 * *$ & $-0.158 * *$ & 0.200 & -0.078 \\
\hline & $(0.088)$ & $(0.147)$ & $(0.125)$ & $(0.098)$ & $(0.198)$ & $(0.131)$ & $(0.072)$ & $(0.192)$ & $(0.108)$ \\
\hline \multirow[t]{2}{*}{$I_{m} \ln (R \& D /$ labour $)$} & 0.017 & 0.064 & -0.016 & $0.072 * *$ & $0.441 * * *$ & 0.057 & -0.013 & 0.031 & 0.020 \\
\hline & $(0.024)$ & $(0.042)$ & $(0.032)$ & $(0.036)$ & $(0.058)$ & $(0.036)$ & $(0.029)$ & $(0.069)$ & $(0.035)$ \\
\hline \multirow{2}{*}{$\begin{array}{l}\mathrm{I}_{\mathrm{m}} \ln (\mathrm{R} \& \mathrm{D} / \text { labour })^{2} \\
/ 2\end{array}$} & 0.002 & 0.002 & 0.039 & -0.021 & $0.056^{* * *}$ & 0.023 & -0.026 & -0.002 & -0.026 \\
\hline & $(0.019)$ & $(0.003)$ & $(0.026)$ & $(0.028)$ & $(0.013)$ & $(0.024)$ & $(0.021)$ & $(0.002)$ & $(0.025)$ \\
\hline \multirow[t]{2}{*}{$I_{b} \ln (T P /$ labour $)$} & 0.080 & 0.120 & -0.036 & -0.012 & $-0.214^{* *}$ & 0.113 & 0.052 & $0.376^{* * *}$ & -0.015 \\
\hline & $(0.057)$ & $(0.100)$ & $(0.067)$ & $(0.053)$ & $(0.105)$ & $(0.086)$ & $(0.049)$ & $(0.106)$ & $(0.067)$ \\
\hline \multirow[t]{2}{*}{$I_{b} \ln (T P / \text { labour })^{2} / 2$} & 0.032 & 0.004 & 0.017 & -0.112 & $-0.004 * *$ & $-0.191 *$ & 0.019 & 0.036 & -0.029 \\
\hline & $(0.055)$ & $(0.004)$ & $(0.079)$ & $(0.079)$ & $(0.001)$ & $(0.098)$ & $(0.030)$ & $(0.028)$ & $(0.041)$ \\
\hline $\mathrm{I}_{\mathrm{bm}} \ln (\mathrm{R} \& \mathrm{D} /$ labour $)$ & -0.029 & 0.005 & 0.009 & 0.087 & $0.022 * *$ & 0.098 & 0.011 & -0.004 & 0.040 \\
\hline$* \ln (\mathrm{TP} /$ labour $)$ & $(0.056)$ & $(0.003)$ & $(0.053)$ & $(0.091)$ & $(0.012)$ & $(0.085)$ & $(0.042)$ & $(0.009)$ & $(0.026)$ \\
\hline \multirow[t]{2}{*}{ SOE } & -0.057 & 0.090 & 0.105 & 0.076 & 0.065 & 0.087 & $0.210^{* *}$ & -0.175 & 0.136 \\
\hline & $(0.056)$ & $(0.128)$ & $(0.094)$ & $(0.091)$ & $(0.198)$ & $(0.111)$ & $(0.083)$ & $(0.178)$ & $(0.083)$ \\
\hline \multirow[t]{2}{*}{ FOREIGN } & 0.073 & $0.304 * *$ & 0.083 & 0.005 & $-0.354 * *$ & -0.075 & 0.091 & $0.298^{*}$ & -0.011 \\
\hline & $(0.089)$ & $(0.126)$ & $(0.106)$ & $(0.074)$ & $(0.157)$ & $(0.102)$ & $(0.079)$ & $(0.179)$ & $(0.088)$ \\
\hline \multirow[t]{2}{*}{ AGE } & -0.002 & $-0.012 * * *$ & $-0.006 * *$ & -0.000 & $-0.027 * * *$ & -0.001 & -0.001 & -0.003 & -0.001 \\
\hline & $(0.002)$ & $(0.004)$ & $(0.003)$ & $(0.002)$ & $(0.006)$ & $(0.003)$ & $(0.002)$ & $(0.005)$ & $(0.002)$ \\
\hline \multirow{2}{*}{$\begin{array}{l}\text { CAPITAL/labour } \\
\text { (avg 2000-2002) }\end{array}$} & 0.000 & 0.001 & -0.000 & 0.000 & -0.000 & -0.001 & -0.001 & -0.000 & -0.000 \\
\hline & $(0.000)$ & (0.001) & $(0.001)$ & $(0.000)$ & (0.001) & $(0.001)$ & $(0.001)$ & $(0.001)$ & $(0.001)$ \\
\hline \multirow{2}{*}{$\begin{array}{r}\text { PROFIT/labour } \\
\text { (avg 2000-2002) }\end{array}$} & $-0.001 *$ & $0.003^{* * *}$ & 0.001 & -0.001 & $0.017 * * *$ & $0.004^{*}$ & $0.002^{* *}$ & $0.018^{* * *}$ & $0.011^{* * *}$ \\
\hline & $(0.001)$ & $(0.001)$ & $(0.001)$ & $(0.001)$ & $(0.001)$ & $(0.003)$ & $(0.001)$ & $(0.002)$ & $(0.003)$ \\
\hline \multirow[t]{2}{*}{ EXPORT } & 0.042 & -0.152 & -0.000 & $0.164^{*}$ & -0.072 & 0.091 & $0.142^{*}$ & -0.043 & 0.016 \\
\hline & $(0.084)$ & $(0.133)$ & $(0.102)$ & $(0.089)$ & $(0.161)$ & $(0.102)$ & $(0.076)$ & $(0.161)$ & $(0.084)$ \\
\hline \multirow[t]{2}{*}{ R\&D_UNI } & $0.203 * *$ & $0.616^{* * *}$ & $0.197^{*}$ & 0.114 & $0.535^{* * *}$ & 0.120 & 0.069 & $-0.363^{* *}$ & -0.001 \\
\hline & $(0.098)$ & $(0.124)$ & $(0.110)$ & $(0.092)$ & $(0.164)$ & $(0.113)$ & $(0.080)$ & $(0.175)$ & $(0.090)$ \\
\hline \multirow[t]{2}{*}{ R\&D_PRI } & -0.017 & $0.636 * * *$ & 0.038 & 0.140 & 0.114 & 0.121 & -0.013 & 0.135 & -0.032 \\
\hline & $(0.073)$ & $(0.120)$ & $(0.109)$ & $(0.094)$ & $(0.156)$ & $(0.113)$ & $(0.079)$ & $(0.184)$ & $(0.099)$ \\
\hline \multirow[t]{2}{*}{ R\&D_FIRM } & 0.069 & $0.688^{* * *}$ & $0.390 * * *$ & 0.101 & $0.596 * * *$ & $0.324^{* * *}$ & $0.175^{* *}$ & 0.151 & $0.264 * * *$ \\
\hline & $(0.072)$ & $(0.112)$ & $(0.088)$ & $(0.078)$ & $(0.164)$ & $(0.091)$ & $(0.076)$ & $(0.181)$ & $(0.069)$ \\
\hline$\rho$ & & 0.079 & & & $-0.695^{* *}$ & & & $-0.803 * *$ & \\
\hline$\sigma_{n}$ & & 1.233 & & & 1.533 & & & 1.635 & \\
\hline Nb observations & 435 & 159 & 435 & 338 & 176 & 338 & 342 & 210 & 342 \\
\hline
\end{tabular}

*** $\mathrm{p}$-value $0.01, * * \mathrm{p}$-value $0.05, * \mathrm{p}-$ value 0.1 . Industry dummies are included. City dummies are included in the probit for process innovation and in the selection equation for the product innovation. New product sales per employee are in logarithms. $I_{b}$ indicates that $R \& D>0, I_{m}$ indicates that $T P>0, I_{b m}$ indicates that both $R \& D$ and $T P$ are positive.

In columns (1), (4), and (7) we report the marginal effects of the explanatory variables on the incidence of process innovations, and in columns (3), (6), and (9) the marginal effects on the incidence of product innovations. In columns (2), (5), and (8) we report the marginal effects of the explanatory variables on the unconditional expectation of new product sales per employee. Calculations of unconditional marginal effects/elasticities are based on (10)-(14) in Appendix A. When computing the marginal effects of $\mathrm{I}_{\mathrm{b}}$ or $\mathrm{I}_{\mathrm{m}}$, we take into account all the terms where these two dummies appear (i.e. four terms in total). For $\mathrm{I}_{\mathrm{m}} \ln \left(\mathrm{R} \& \mathrm{D} /\right.$ labour) and $\mathrm{I}_{\mathrm{b}} \ln (\mathrm{TP} /$ labour), we include in the computation of the elasticities the effects of the square term and the interaction term. The marginal effects of $\mathrm{I}_{\mathrm{m}} \ln (\mathrm{R} \& \mathrm{D} / \mathrm{labour})^{2} / 2$ 
and $\mathrm{I}_{\mathrm{b}} \ln (\mathrm{TP} / \text { labour })^{2} / 2$ represent second-order derivatives and the marginal effect of $\mathrm{I}_{\mathrm{m}} \ln (\mathrm{R} \& \mathrm{D} /$ labour $) * \mathrm{I}_{\mathrm{b}} \ln (\mathrm{TP} /$ labour $)$ represents the second-order cross derivative of the unconditional expectation of new product sales/employee. Standard errors are computed using the Delta method.

Table 6 Estimation results of the productivity equation

\begin{tabular}{|c|c|c|c|c|c|c|}
\hline & \multicolumn{2}{|c|}{$<100$ employees } & \multicolumn{2}{|c|}{$>=100 \&<300$ employees } & \multicolumn{2}{|c|}{$>=300$ employees } \\
\hline & OLS & GMM & OLS & GMM & OLS & GMM \\
\hline \multirow[t]{2}{*}{$\ln$ (capital/labour) } & $0.084 * * *$ & $0.182^{* * *}$ & $0.131 * * *$ & $0.082^{* *}$ & $0.183^{* * *}$ & $0.079 * *$ \\
\hline & $(0.016)$ & $(0.049)$ & $(0.023)$ & $(0.038)$ & $(0.027)$ & $(0.032)$ \\
\hline \multirow[t]{2}{*}[\operatorname{ln}(\text{capital}/\text{labour})]{$^{2} / 2$} & 0.001 & -0.010 & -0.009 & 0.019 & 0.019 & 0.029 \\
\hline & $(0.011)$ & $(0.022)$ & $(0.027)$ & $(0.019)$ & $(0.031)$ & $(0.060)$ \\
\hline \multirow[t]{2}{*}{$\ln ($ labour) } & 0.042 & 0.026 & 0.059 & -0.000 & -0.037 & 0.128 \\
\hline & $(0.035)$ & $(0.073)$ & $(0.071)$ & $(0.093)$ & $(0.042)$ & $(0.104)$ \\
\hline \multirow[t]{2}{*}{$\ln ($ material/labour) } & $0.657 * * *$ & $0.619^{* * *}$ & $0.620 * * *$ & $0.627 * * *$ & $0.521 * * *$ & $0.527 * * *$ \\
\hline & $(0.013)$ & $(0.025)$ & $(0.017)$ & $(0.040)$ & $(0.015)$ & $(0.041)$ \\
\hline \multirow[t]{2}{*}[\operatorname{ln}(\text{material}/\text{labour})]{$^{2} / 2$} & $0.130^{* * *}$ & $0.105^{* * *}$ & $0.075^{* * *}$ & $0.107^{* * *}$ & $0.121 * * *$ & $0.050 * *$ \\
\hline & $(0.009)$ & $(0.017)$ & $(0.014)$ & $(0.014)$ & $(0.011)$ & $(0.019)$ \\
\hline \multirow{2}{*}{$\begin{array}{l}\ln (\text { capital/labour) } \\
\quad * \ln (\text { material/labour) }\end{array}$} & $-0.070 * * *$ & -0.029 & $-0.039 * * *$ & 0.011 & $-0.041 * * *$ & -0.017 \\
\hline & $(0.008)$ & $(0.024)$ & $(0.015)$ & $(0.025)$ & $(0.014)$ & $(0.025)$ \\
\hline \multirow[t]{2}{*}{$\mathbf{I}_{\mathrm{m}}$} & $0.112^{*}$ & 0.147 & $0.247 * * *$ & $0.294 * * *$ & $0.269 * * *$ & $0.177^{*}$ \\
\hline & $(0.060)$ & $(0.092)$ & $(0.074)$ & $(0.101)$ & $(0.074)$ & $(0.089)$ \\
\hline \multirow[t]{2}{*}{$\mathbf{I}_{\mathbf{b}}$} & 0.222 & $0.692 * * *$ & -0.157 & $0.387 * * *$ & 0.269 & 0.476 \\
\hline & $(0.270)$ & $(0.261)$ & $(0.182)$ & $(0.117)$ & $(0.284)$ & $(0.796)$ \\
\hline \multirow[t]{2}{*}{$\mathbf{I}_{\mathrm{bm}}$} & -0.197 & $-0.939 * * *$ & -0.016 & $-0.498 * * *$ & -0.692 & $-0.581 * * *$ \\
\hline & $(0.283)$ & $(0.288)$ & $(0.316)$ & $(0.148)$ & $(0.658)$ & $(0.196)$ \\
\hline \multirow[t]{2}{*}{$I_{m} \ln (R \& D /$ labour $)$} & 0.013 & 0.051 & 0.037 & $0.110 * * *$ & $0.037^{*}$ & 0.049 \\
\hline & $(0.024)$ & $(0.035)$ & $(0.026)$ & $(0.036)$ & $(0.021)$ & $(0.031)$ \\
\hline \multirow[t]{2}{*}{$\mathrm{I}_{\mathrm{m}} \ln (\mathrm{R} \& \mathrm{D} / \text { labour })^{2} / 2$} & 0.024 & -0.006 & 0.003 & -0.008 & -0.012 & -0.005 \\
\hline & $(0.019)$ & $(0.018)$ & $(0.018)$ & $(0.016)$ & $(0.014)$ & $(0.015)$ \\
\hline \multirow[t]{2}{*}{$I_{b} \ln (T P /$ labour $)$} & 0.005 & -0.080 & 0.069 & 0.004 & 0.057 & $0.100^{* * *}$ \\
\hline & $(0.058)$ & $(0.054)$ & $(0.045)$ & $(0.050)$ & $(0.036)$ & $(0.032)$ \\
\hline \multirow{2}{*}{$I_{b} \ln (T P / \text { labour })^{2} / 2$} & 0.015 & -0.036 & 0.039 & -0.016 & 0.011 & $0.031 * *$ \\
\hline & $(0.063)$ & $(0.035)$ & $(0.045)$ & $(0.029)$ & $(0.021)$ & $(0.014)$ \\
\hline \multirow{2}{*}{$\begin{array}{c}\mathrm{I}_{\mathrm{bm}} \ln (\mathrm{R} \& \mathrm{D} / \text { labour }) \\
* \ln (\mathrm{TP} / \text { labour })\end{array}$} & 0.014 & $0.073 * *$ & 0.002 & 0.013 & 0.006 & 0.005 \\
\hline & $(0.037)$ & $(0.029)$ & $(0.028)$ & $(0.021)$ & $(0.012)$ & $(0.009)$ \\
\hline \multirow[t]{2}{*}{ SOE } & -0.080 & -0.137 & $-0.228 * * *$ & -0.072 & $-0.362 * * *$ & $-0.336 * * *$ \\
\hline & $(0.058)$ & $(0.107)$ & $(0.069)$ & $(0.106)$ & $(0.049)$ & $(0.075)$ \\
\hline \multirow[t]{2}{*}{ FOREIGN } & $0.221 * * *$ & $0.286^{* * *}$ & $0.221 * * *$ & $0.215^{* * *}$ & $0.132 * *$ & $0.171 * *$ \\
\hline & $(0.070)$ & $(0.088)$ & $(0.064)$ & $(0.067)$ & $(0.055)$ & $(0.069)$ \\
\hline \multirow[t]{2}{*}{ EXPORT } & 0.019 & 0.007 & $0.111 *$ & 0.076 & $0.202 * * *$ & $0.150^{* *}$ \\
\hline & $(0.069)$ & $(0.081)$ & $(0.061)$ & $(0.062)$ & $(0.053)$ & $(0.062)$ \\
\hline \multirow[t]{2}{*}{ Constant } & $1.602^{* * *}$ & $1.576^{* * *}$ & $1.542 * * *$ & 1.152 & $2.278^{* * *} *$ & 0.628 \\
\hline & $(0.209)$ & $(0.395)$ & $(0.412)$ & $(0.906)$ & $(0.418)$ & $(0.967)$ \\
\hline R-squared & 0.775 & - & 0.707 & - & 0.744 & - \\
\hline Hansen overidentification test & & $\operatorname{chi} 2(56): 57.46$ & & chi2(56): 56.34 & & chi2(56): 66.07 \\
\hline Prob > chi 2 & & 0.384 & & 0.462 & & 0.091 \\
\hline Difference-in-Hansen test & & chi2(28): 32.02 & & chi2(28): 31.80 & & chi2(28): 24.10 \\
\hline Prob > chi2 & & 0.231 & & 0.283 & & 0.625 \\
\hline Nb observations & 1,304 & 1,304 & 1,026 & 1,026 & 1,002 & 1,002 \\
\hline
\end{tabular}

*** $\mathrm{p}$-value $0.01,{ }^{* *} \mathrm{p}$-value $0.05{ }^{*}$ p-value 0.1 . Industry and year dummies are included. When computing the marginal effects of $\mathrm{I}_{\mathrm{b}}$ or $\mathrm{I}_{\mathrm{m}}$ we take into account all the terms where these two dummies appear (i.e. five terms in total). For $\mathrm{I}_{\mathrm{m}} \ln (\mathrm{R} \& \mathrm{D} /$ labour $)$ and $\mathrm{I}_{\mathrm{b}} \ln (\mathrm{TP} /$ labour$)$, we include in the computation of the elasticities the effects of the 
square term and the interaction term. The marginal effects of $\mathrm{I}_{\mathrm{m}} \ln (\mathrm{R} \& \mathrm{D} / \text { labour })^{2} / 2$ and $\mathrm{I}_{\mathrm{b}} \ln (\mathrm{TP} / \text { labour })^{2} / 2$ represent second-order derivatives and the marginal effect of $\mathrm{I}_{\mathrm{m}} \ln (\mathrm{R} \& \mathrm{D} / \mathrm{labour}) * \mathrm{I}_{\mathrm{b}} \ln (\mathrm{TP} /$ labour $)$ represents the second-order cross derivative of the unconditional expectation of new product sales/employee. For the marginal effects of $\ln$ (capital/labour) and $\ln$ (material/labour), square term and the interaction term are also accounted. Standard errors are computed using the Delta method. The marginal effects are evaluated at the means of the variables and only for positive values for R\&D and TP. 